\title{
Peripheral and cardiac consequences of diminished nitric oxide production
}

\author{
Gábor Molnár MD
}

Ph.D. Thesis

Institute of Surgical Research, University of Szeged, Department of Surgery, Dr. Istvan Bugyi Hospital, Szentes, Hungary

Szeged 


\section{List of full papers related to the subject of the thesis}

1. Eszlári E, Czóbel M, Molnár G, Bogáts G, Kaszaki J, Nagy S, Boros M: Modulation of cardiac contractility through endothelin-1 release and myocardial mast cell degranulation. Acta Physiol Hun 95:301-319, 2008.

IF 0.491

2. Czóbel M, Kaszaki J, Molnár G, Nagy S, Boros M: Nonspecific inhibition of nitric oxide synthesis evokes endothelin-dependent increases in myocardial contractility. Nitric Oxide Biol Chem 21: 201-209, 2009.

IF 2.506

3. Molnár G, Eszlári E, Czóbel M, Kaszaki J, Bogáts G, Nagy S, Boros M: A nitrogénmonoxid-szintézis gátlása endothelinfüggő szívkontraktilitás növekedéshez vezet. Cardiologica Hungarica 40(1): 1-6, 2010.

IF 0.0

4. Molnár G, Csonka E, Vass A, Boros M, Kaszaki J: Circulatory consequences of reduced endogenous nitric oxide production during small-volume resuscitation. Acta Physiol Hung 98: 393-408, 2011.

IF 1.2

\section{List of abstracts related to the subject of the thesis}

1. Molnár G., Kaszaki J., Nagy S., Petri I., Balogh Á., Boros M.: Vazoaktív mediátorok szerepe a kolloid-krisztalloid volumen expanderek keringési hatásaiban. Magyar Sebészet 52: 215, 1999.

2. Kaszaki J, Eszlári E, Csonka E, Molnár G., Boros M: A kolloid-krisztalloid volumen expanzió következményei: hízósejtek és az endothelin-1 szerepe. Magyar Sebészet Suppl: 20, 2001.

3. Kaszaki J., Molnár G., Nagy S., Balogh Á., Boros M.: The role of endothelin and nitric oxide in the circulatory effects of colloid-crystalloid resuscitation fluids. J. Physiol. 526P: 127P, 2000.

4. Kaszaki J., Molnár G., Nagy S., Balogh Á., Boros M.: The role of vasoactive mediators in the circulatory effects of colloid-crystalloid volume expansion. European Surgical Research 32 (Supp1 1.): p57, 2000.

5. Molnár G., Kaszaki J., Eszlári E., Géczi T., Nagy S., Petri I., Boros M.: Interaction of endothelin and nitric oxide in cardiac effects of colloid-crystalloid volume expansion. Perfusion 8: 366, 2000.

6. Kaszaki J., Molnár G., Eszlári E., Csonka E., Nagy S., Petri I., Boros M.: The role of mast cells and endothelin-1 in the circulatory effects of colloid-crystalloid resuscitation fluids. European Surgical Research 33: 155, 2001. 


\section{CONTENTS}

List of papers related to the subject of the thesis 1

List of abbreviations 3

Summary 4

1. Introduction 5

1.1. Generation of nitric oxide 5

1.2. Circulatory effects of nitric oxide 5

1.3. Nitric oxide and cardiac function 6

1.4. Pathophysiological consequences of diminished nitric oxide production 8

1.5. Significance of hypertonic fluid resuscitation in circulatory disturbances 9

2. Main goals 11

3. Materials and Methods $\quad 12$

3.1. Surgical preparation 12

3.2. Macrohemodynamic measurements 13

$\begin{array}{ll}\text { 3.3. Biochemical measurements } & 13\end{array}$

3.4. Experimental protocols 15

3.5. Statistical analysis 16

4. Results 17

4.1. Study I: Cardiac and peripheral effects of NNA treatment 17

4.2. Study II: Early and late effects of nitric oxide on the small volume resuscitation 23

5. Discussion 30

5.1. Discussion of Study I 30

5.2. Discussion of Study II 34

6. Summary of new findings 39

$\begin{array}{ll}7 . & \text { References }\end{array}$

8. Acknowledgments 50

9. Annex 51 


\section{LIST OF ABBREVIATIONS}

$\begin{array}{lll}\text { cAMP } & - & \text { cyclic adenosine monophosphate } \\ \text { cGMP } & - & \text { cyclic guanosine monophosphate } \\ \text { CI } & - & \text { cardiac index } \\ \text { cNOS } & - & \mathrm{Ca}^{2+} \text {-dependent constitutive nitric oxide synthase } \\ \text { CO } & - & \text { cardiac output } \\ \text { CVP } & - & \text { central veous pressure } \\ \text { eNOS } & - & \text { endothelial nitric oxide synthase } \\ \text { ET } & - & \text { endothelin } \\ \text { ET-A } & - & \text { endothelin-A receptor } \\ \text { HR } & - & \text { heart rate } \\ \text { HS } & - & \text { hypertonic saline } \\ \text { HSD } & - & \text { hypertonic saline }- \text { dextran solution } \\ \text { iNOS } & - & \text { Ca }{ }^{2+} \text {-independent inducible nitric oxide synthase } \\ \text { LV } & - & \text { left ventricular } \\ \text { LVD } & - & \text { left ventricular diameter } \\ \text { LVP } & - & \text { left ventricular pressure } \\ \text { MAP } & - & \text { mean arterial pressure } \\ \text { MPO } & - & \text { myeloperoxidase } \\ \text { NNA } & - & \text { N- } \omega \text {-nitro-L-arginine } \\ \text { nNOS } & - & \text { neuronal nitric oxide synthase } \\ \text { NO } & - & \text { nitric oxide } \\ \text { NOS } & - & \text { nitric oxide synthase } \\ \text { TPR } & - & \text { total peripheral vascular resistance } \\ \text { XOR } & - & \text { xanthine oxidoreductase } \\ \text { mo } & & \end{array}$




\section{SUMMARY}

Nitric oxide (NO) is a broad-spectrum regulator of the cardiovascular system. A variable-level, but steady generation of NO is achieved by a family of isoenzymes. Although NO is regarded as predominantly a peripheral vasoactive mediator, the mammalian heart also expresses all three isoforms of NO synthase (NOS), and NO has several specific effects on the normal myocardium too. The role of endogenous NO in modulating myocardial contractility is still unclear, in part because of unknown, secondary effects of blocking NO release.

In the treatment of acute circulatory failure, small-volume resuscitation with hypertonic saline-dextran (HSD) solutions effectively improves the cardiovascular function and it has proved much more efficient than normotonic volume replacement. The primary target organ of fluid replacement is the vascular endothelium, a sensitive sensory and transmitter surface between the circulating blood and the wall of the vessels throughout the body, where several vasoactive mediators of endothelial origin are synthesized and released. Physiologically, the most important stimulus for the continuous formation of NO is the viscous drag (shear stress) generated by the streaming blood on the endothelial layer.

Given this background, the general aim of our studies was to examine and characterize the consequences of artificially diminished NO production in a large animal model by using the L-arginine analog nonselective NOS inhibitor $N^{\mathrm{G}}$-nitro-L-arginine (NNA) on the central and peripheral circulatory patterns in normovolemia and during hyperosmotic colloid fluid therapies.

The results of Study I revealed that a diminished NO production leads to secondary reactions, whereby a mismatch between NO supply and demand in the cardiac muscle is translated into an increase in cardiac contractility. A reduced NO synthesis leads to increased superoxide production and preponderant vasoconstrictor effects, which decrease cardiac output (CO) and increase the myocardial contractility through an endothelin-A (ET-A) receptor-dependent mechanism. The results of Study II indicate that the generation of vasoactive mediators is involved in HSD-caused circulatory changes and in alterations in cardiac contractility through NO-dependent and independent mechanisms, and suggest the preponderance of ET-1 in this process. Furthermore it can be concluded that HSD is less effective in NO-deficient states.

These experimental data point to a suppressive, regulatory role for endogenous NO: it restrains or counteracts several mechanisms which would otherwise increase the cardiac contractility. The bioavailability of NO or its amount relative to other, vasoregulator, inotropic agents is of crucial importance. 


\section{INTRODUCTION}

\subsection{Generation of nitric oxide}

NO is one of the few gaseous signaling molecules known and is additionally exceptional by virtue of the fact that it is a radical gas. It is a key vertebrate biological messenger, playing a role in a variety of biological processes. NO, known as the "endothelium-derived relaxing factor", is biosynthesized endogenously from L-arginine, oxygen and NADPH by various forms of NOS, leading to the formation of L-citrulline and NO (Palmer 1988). A variable-level, but steady generation of NO is achieved by a family of isoenzymes, including neuronal NOS (nNOS or NOS1), inducible NOS (iNOS/NOS2) and endothelial NOS (eNOS/NOS3). Constitutive types of NOS (cNOS) are $\mathrm{Ca}^{2+} / \mathrm{calmodulin}-$ dependent, while iNOS is $\mathrm{Ca}^{2+}$-independent. cNOS is responsible for the production of NO in a physiological context (Massion 2003). In contrast, iNOS produces NO under pathophysiological circumstances. nNOS was first described in the neurons of the central and peripheral nervous systems, while eNOS is present in the endothelium of blood vessels. It has been shown that all three types of NOS can be found in almost all cells of the body. NO is highly reactive (having a lifetime of a few seconds), yet diffuses freely across membranes. These attributes make NO ideal as a transient paracrine and autocrine signaling molecule (Moncada 1991).

\subsection{Circulatory effects of nitric oxide}

NO produced by NOS isoenzymes is a fundamental determinant of cardiovascular homeostasis: it regulates the systemic blood pressure, vascular remodeling and angiogenesis. NO contributes to vessel homeostasis by inhibiting vascular smooth muscle contraction and growth, platelet aggregation and leukocyte adhesion to the endothelium.

NO is produced by many cells in the body; however, its production by the vascular endothelium is particularly important in the regulation of the blood flow. As a short-lived powerful mediator, it has a rapid vasodilatatory effect. There are two basic pathways for the stimulation of cNOS, both of which involve the release of $\mathrm{Ca}^{2+}$ from subsarcolemmal storage sites. First, shearing forces acting on the vascular endothelium, generated by the blood flow, cause a release of $\mathrm{Ca}^{2+}$ and subsequent cNOS activation. Increases in blood flow therefore, stimulate NO formation (flow-dependent NO formation).

Second, endothelial receptors for a variety of ligands stimulate $\mathrm{Ca}^{2+}$ release and subsequent NO production (receptor-stimulated NO formation). The list includes receptors for acetylcholine, bradykinin, substance $\mathrm{P}$, adenosine and many other vasoactive substances. These effects have been attributed to NO production by the eNOS; however, recent evidence 
suggests that nNOS also has a distinct local role in the physiological regulation of the human microvascular tone (Seddon 2008).

NO is additionaly generated by phagocytes (monocytes, macrophages and neutrophils) as part of the human immune response. Phagocytes are armed with iNOS. In this way the immune system may regulate the armamentarium of phagocytes that play a role in inflammation and immune responses (Hibbs 1988). Under normal, resting conditions, the activity of iNOS is very low. The activity of iNOS is stimulated during inflammation by bacterial endotoxins (e.g. lipopolysaccharide) and cytokines such as tumor necrosis factor alfa and interleukins. During inflammation, the amount of NO produced by iNOS may be $1,000-$ fold greater than that produced by cNOS. This latter enzyme activity leading to high-output NO synthesis was initially perceived to act as a toxic defense mechanism associated with local tissue destruction in chronic inflammatory conditions (Steiner 1997). However, more recent investigations have linked a powerful protective activity toward cellular stress conditions with iNOS-derived NO synthesis (Buttery 1996, Suschek 1999).

\subsection{Nitric oxide and cardiac function}

Although NO is a primary determinant of the blood vessel tone, the recognition that all three isoforms of NOS are expressed in cardiomyocytes themselves has raised several intriguing questions regarding the signaling role of NO in the heart (Massion 2003).

The modulatory effects of NO on the cardiac function are undoubtedly complex (Kelly 1996, Shah 2000, Brutsaert 2003, Casadei 2003). They involve the enhancement of myocardial relaxation and the diastolic function (Shetty 1993, Paulus 1994, Casadei 2003), an increase or decrease in $\beta$-adrenergic responses (Balligand 1993, Keaney 1996), modulation of the force-frequency relationship (Cotton 2001) and the mediation of parasympathetic cholinergic effects (Han 1994). This is perhaps expected when one considers the versatility of NO biochemistry, the multiplicity of its intracellular targets (with sometimes opposite contractile influences), and the diversity of its cellular sources within the myocardium.

NO has beneficial actions on myocardial energetics and the left ventricular (LV) diastolic distensibility. In isolated cardiomyocytes, the administration of NO increases their diastolic cell length consistently with a shift to the right of the passive length-tension relation. This shift is explained by the cGMP-induced phosphorylation of troponin I, which prevents $\mathrm{Ca}^{2+}$-independent diastolic cross-bridge cycling and concomitant diastolic stiffening of the myocardium (Shah 1994, Ito 1997). After adrenoreceptor stimulation of isolated cardiac muscle strips, the NO-induced relaxation effect was larger, probably because of the simultaneous phosphorylation of troponin I by cAMP-dependent and cGMP-dependent 
protein kinases (Mohan 1996). A beneficial effect of high endomyocardial NO activity on the diastolic LV distensibility of the cardiomyopathic heart could also result from the prevention of endomyocardial fibrosis.

The effects of NO on the diastolic LV performance appear to be synergistic with its effects on myocardial energetics through prevention of myocardial energy wastage induced by LV contraction against late-systolic reflected arterial pressure waves (Rourke 1999) and through the prevention of diastolic LV stiffening, which is essential for the maintenance of adequate subendocardial coronary perfusion.

The exact role of endogenous NO production in the regulation of the cardiac contractility is still controversial (Balligand 1993, Brady 1993, Kojda 1996, Barouch 2002), mainly because of the disproportionate extrapolation from results relating to modulation of the NO output. The consequences of altered NO production may be studied with NO donors, NOS inhibition and genetically modified models, and there is in vivo evidence that the lack of NO leads to an increased myocardial contractility in dogs (Kaszaki 1996, Keaney 1996, Kilbourn 1997). In contrast, it has also been found that blockade of the NO/cGMP pathway with NOS inhibitors in rats and in isolated guinea pig cardiac myocytes points to the negative inotropic effect of NO (Kojda 1997, Barouch 2002). Similarly, studies with eNOS-deficient mouse strains have yielded contradictory results (Brunner 2001, Barouch 2002). While the positive inotropic response is enhanced in eNOS-deficient mice (Gyurko 2000, Barouch 2002), this effect was not present when isolated cardiomyocytes from eNOS knock-out mice were used (Godecke 2001). In the basal state or under low $\beta$-adrenergic stimulation, the effects of NO are bimodal, with a positive inotropic effect at low-level NO exposure, but a negative one at higher amounts (Casadei 2003, Massion 2003).

A possible explanation for these contrasting results could be that the cardiac reactions of NO are achieved via additional circulatory effectors. Under physiological conditions, peripherally released NO not only exerts effects on the vasculature, but also significantly influences the reactions of other cell types in the circulatory system. The roles and relationships of these secondary mechanisms in modulating the NO-linked myocardial responses are largely unknown, and it could be argued that NO may affect other pathways which lead indirectly to myocardial contractility changes.

At higher NO exposure in the case of sepsis, large concentrations of iNOS-derived NO overwrite the above mechanisms and steeply depress the cardiac contractile performance through cGMP-mediated and protein kinase G-mediated desensitization of cardiac 
myofilaments (Tavernier 2001). A similar mechanism may depress the basal cardiac function in mice overexpressing large amounts of eNOS (Brunner 2001).

As a radical gas, NO has a lifetime of only a few seconds. Its bioavailability on its specific targets depends greatly on certain bioactive agents. Free radical scavengers such as myoglobin, particularly abundant in the cardiomyocytes, inhibit NO availability. Accordingly, the effects of NO donors and endogenous NO on the contractile force are enhanced in hearts from myoglobin-deficient mice (Flogel 2001). Reactive oxygen intermediates and NO mutually influence the bioavailability of each other, production and actions in a multi-level manner. They create peroxynitrite, a known inhibitor of NOS activity (Sheehy 1998, Ovadia 2002). This compound has also been associated with a depressed cardiac pump function through myocardial protein nitration.

\subsection{Pathophysiological consequences of diminished nitric oxide production}

The integrity of the endothelium is essential for this flow-mediated vasodilation (Davies 1993), which is largely due to the release of NO, although in some vascular beds prostacyclin, endothelium-derived hyperpolarizing factor, or direct activation of an $\mathrm{K}^{+}$ channels may contribute (Pohl 1986). Furthermore, it has been demonstrated that endothelial dysfunction is associated with reduced NO bioavailability in the cardiovascular system (Dixon 2005).

Studies have identified hemodynamic shear stress as an important determinant of endothelial function and phenotype. Arterial-level shear stress ( $>15$ dyne $\mathrm{cm}^{-2}$ ) induces endothelial quiescence and an atheroprotective gene expression profile, while low shear stress ( $<4$ dyne $\mathrm{cm}^{-2}$ ), which is prevalent at atherosclerosis-prone sites, stimulates an atherogenic phenotype (Malek 1999).

Disturbances of flow-mediated vasodilation may have pathophysiological consequences. Humans with atherosclerosis, diabetes or hypertension often exhibit impaired NO pathways. In patients with coronary artery disease and impairment of the endothelial vasodilatory function, increases in blood flow through the diseased coronary artery cause a paradoxical vasoconstriction, which can contribute to myocardial ischemia during exercise or mental stress (Pedersen 1997). Proliferation of vascular smooth muscle is seen in states of endothelial dysfunction that are characterized by a reduced release of NO, providing further support for its role in regulating the vascular structure. It is often observed following balloon injury that the myointimal proliferation continues even after the vessel wall has been resurfaced by endothelium. These cells appear to release less NO, as manifested by an attenuation of endothelium-dependent relaxations in these vessels (Weidinger 1990). In 
hypercholesterolemic animals and man, endothelium-dependent relaxation is reduced and vasoconstriction is enhanced. This is largely due to a reduction in NO activity and not to the physical absence of the endothelium (Drexler 1991).

Increasing evidence indicates that endothelium-derived NO may act to oppose the hypercholesterolemia-induced alterations in the endothelial redox state. In the normocholesterolemic rabbit thoracic aorta, there is a basal production of superoxide anion by non-endothelial cells (Ohara 1993). Exogenous NO donors significantly reduce the generation of superoxide anion. When neutrophils are exposed to NO, their ability to generate superoxide anion is limited (Clancy 1992). Specifically, in the context of atherogenesis, NO has been demonstrated to inhibit thrombosis, cytokine-induced vascular cell adhesion molecule-1 expression, leukocyte adhesion to the endothelium, and smooth muscle proliferation and migration (Malek 1995). Together, these observations suggest that NO is an important atheroprotective molecule (Topper 1996).

\subsection{Significance of hypertonic fluid resuscitation in circulatory disturbances}

Adequate volume replacement is of great significance in the therapy of the circulatory disturbances in cases of both perioperative and intensive care attendance. The main goal of fluid therapy is to ensure an adequate oxygen supply for the organs. The individual volume therapy during surgical procedures in normovolemic cases often plays a crucial role in successful management. This essential role is also important throughout the whole perioperative phase (Vollmar 2004).

Small-volume resuscitation using hyperosmotic, colloid-crystalloid solutions effectively improves the cardiovascular function and it has proved much more efficient than normotonic volume replacement (Velasco 1980, Kramer 1986, Armistead 1989). Hypertonic saline (HS) solutions were originally developed for prehospital use and designed to replace larger volumes of isotonic solutions. The reasons for using a standard dose of $4 \mathrm{ml} \mathrm{kg}^{-1} \mathrm{HS}$ or hypertonic saline-dextrane (HSD), seem to be based more on practicality rather than on any true physiologic concept.

Hyperosmotic solutions cause a plasma volume expansion by withdrawing water from the extravascular space, reducing the extravascular pressure, increasing the circulating volume and creating favorable histological pressure conditions at the level of the capillaries (Frohlich 1966). As a result, they effectively improve the cardiovascular function and reduce the total peripheral resistance, thereby enhancing the capillary circulation, and improving the perfusion of hypoperfused organs. In the long run, hyperosmotic solutions increase the amount of 
oxygen available in the body through increasing the blood pressure and $\mathrm{CO}$ and reducing the resistance.

Dextran-based hyperosmotic solutions are known to be effective in restoring the macrohemodynamics (Kramer 1986, Dries 1996). By adding them to HS solution, this effect can be enhanced and, at the same time, swelling of the endothelial cells can be prevented (Mazzoni 1990). The most beneficial hemorheological properties of dextran are the inhibition of erythrocyte and thrombocyte aggregation and adhesion, changing the surface polarization of erythrocytes and endothelial cells (Rutherford 1988), and decreasing the activity of Factor VIII (Bergentz 1978). According to recent studies, high molecular weight dextran (dextran500) attaches to the endothelial surface more effectively than do low molecular weight dextrans (dextran-20, -40 or -70 ), which are commonly used in medicine (Gonzalez-Castillo 2002). The protective role of low molecular weight dextran may therefore become questionable.

Since the primary target organ of fluid replacement is the vascular endothelium, it can play a very significant role in resuscitation. This sensitive sensory and transmitter surface between the circulating blood and the wall of the vessels (Hecker 1993) througout the body is the site where several vasoactive mediators of endothelial origin are synthesized and released (Miller 1992, Kuchan 1993). Infused HSD solution presents a considerable mechanical stimulus for the endothelial cells, partly due to increase in the shear stress affecting the surface, and also because of the hyperosmotic effect. Several experimental and clinical studies have investigated the efficacy, dosages and infusion rates of different hyperosmotic solutions: primarily $7.5 \%$ HS administered alone or in combination with dextran or hetastarch (Wade 1991, Kreimeier 1993). Although the clinical data do not indicate that the administration of hypertonic solutions increases mortality in the clinical setting (Wade 1997, Younes 1997), the results of experimental studies suggest that the administration of HS exacerbates bleeding from injured vessels and leads to early death in anesthetized animals (Vassar 1990, Krausz 1995). 


\section{MAIN GOALS}

The general aim of our studies was to analyze the effects of decreased NO production on the central and peripheral circulatory patterns in normovolemia and during fluid therapies. Since the nonspecific inhibition of NOS is linked to several secondary reactions, our primary goal was to devise a study design that helps to identify a causal chain mechanism relevant to a single cause - multiple effect phenomenon. This approach was used to establish NO-linked contractility responses.

In a second series of experiments, a further goal was to examine the clinical consequences of a rapid volume expansion after the administration of a hypertonichyperoncotic solution. To this end, we employed a 7.2\% hypertonic saline-10\% dextran-40 (HSD) solution to induce rapid changes in the cardiac hemodynamics with or without nonspecific NOS inhibitor pretreatment.

- Study I characterized the myocardial contractility consequences of pharmacologically decreased NO production in a large animal model by using the L-arginine analog aspecific NOS inhibitor $N^{\mathrm{G}}$-nitro-l-arginine (NNA) and the NO dependence of several secondary variables was examined.

- Study II was designed to explore a connection between the increased peripheral flowinduced changes and cardiac contractility alterations. In this, setup we outlined the role of NO in the HSD-evoked hemodynamic changes, and investigated the effects of smallvolume resuscitation in conditions associated with diminished NO production. 


\section{MATERIALS AND METHODS}

The experiments were performed in adherence to the NIH guidelines for the use of experimental animals. The study was approved by the Ethical Committee for the Protection of Animals in Scientific Research at the University of Szeged.

\subsection{Surgical preparation}

The experiments were performed on a total of 52 inbred mongrel dogs (average weight $17 \pm 2.8 \mathrm{~kg})$. Anesthesia was induced with sodium pentobarbital $\left(30 \mathrm{mg} \mathrm{kg}^{-1}\right.$ iv $)$ and sustained with $0.2 \mathrm{mg} \mathrm{kg}^{-1} \mathrm{~h}^{-1}$ supplementary doses. After intubation of the trachea, the animals were mechanically ventilated with room air (Harvard Apparatus, South Natick, MA, U.S.A.). The left femoral artery and vein were cannulated for the measurement of mean arterial pressure (MAP) and the administration of drugs and fluids, respectively. Blood gas parameters were regularly controlled throughout the experiments. The animals received $15 \mathrm{ml} \mathrm{kg}^{-1} \mathrm{~h}^{-1}$ Ringer's lactate infusion during Study I. In Study II, an identical dose of Ringer's lactate was given until the start of HSD treatment. A Swan-Ganz thermodilution catheter (Corodyn TD-E-N, 5011-110-7Fr; Braun Melsungen AG, Melsungen, Germany) was positioned into the pulmonary artery via the right femoral vein to measure and calculate the $\mathrm{CO}$ and the cardiac index (CI).

In Studies I and II, an inflatable balloon-catheter (Foley catheter, 14Fr, Kendall Company Ltd., Basingstoke, U.K.) was introduced into the inferior caval vein via the left jugular vein. The filling volume was $10 \mathrm{ml}$. A catheter tip micromanometer (Millar Instruments Inc., Houston, TX, U.S.A.) was introduced into the left ventricle through the left internal carotid artery to monitor the LV pressure (LVP). A left thoracotomy was performed at the sixth intercostal space and the pericardium was opened. A pair of ultrasonic dimension crystals (3 MHz, ID-4, Custom Transducers, Poway, CA, U.S.A.) were sutured onto the anterior and posterior walls of the left ventricle, opposite each other, using an atraumatic surgical technique for measurement of the LV diameter (LVD). The thoracic cavity was revised and the chest wall was closed in four layers. The air was removed from the thorax; the animals were then breathing spontaneously. Their body temperature was maintained at $38{ }^{\circ} \mathrm{C}$ with a homeothermic blanket. At the end of the experiments, a myocardial tissue biopsy sample was taken from the left ventricle and the animals were killed with an overdose of pentobarbital.

In Studies II, to measure coronary blood flow, an ultrasonic flow probe (Transonic Systems, Ithaca, NY, USA) was placed around the left circumflex coronary artery supplying the left ventricle. 


\subsection{Macrohemodynamic measurements}

All hemodynamic signals (pressures, LVP, LVD and coronary flow) were registered with a computerized data-acquisition system (SPEL Advanced Haemosys 2.72, Experimetria Ltd., Budapest, Hungary). The MAP and central venous pressure (CVP) were monitored with Statham P23Db transducers. The heart rate (HR) was calculated from the MAP curve. The CO was determined by thermodilution, using a Cardiostar CO-100 computer (Experimetria Ltd., Budapest, Hungary), normalized for body weight and expressed as CI ( $\left.\mathrm{ml} \mathrm{kg}^{-1} \mathrm{~min}^{-1}\right)$. The total peripheral vascular resistance (TPR) was calculated via the standard formula.

The ultrasonic dimension crystals were connected to a sonomicrometer (Triton Technology, Inc., San Diego, CA, U.S.A.). Via the LVP and LVD signals, the end-systolic elastance, as a parameter of the LV myocardial contractility, was estimated from the slope of the end-systolic pressure vs diameter relationship (Goldfarb 1982, Kaszaki 1996) with a computer program developed by our group. The inferior caval vein was briefly occluded by a balloon catheter, and the pressure $v s$ diameter loops were registered for $8 \mathrm{~s}$. The end-systolic points of the loops (which can be fitted to a sigmoid curve) were recorded. The linear part of the curve was selected on the basis of the lowest variance, and a straight line was fitted to the selected points. The computer program calculated contractility as the slope of the end-systolic pressure $v s$ diameter relationship, and the variance of fitting was determined. The calculation was based on a minimum of 8 cardiac cycles.

\subsection{Biochemical measurements}

\section{Plasma ET-1 measurements}

Two-ml blood samples were drawn from the jugular vein into chilled polypropylene tubes containing EDTA ( $\left.1 \mathrm{mg} \mathrm{ml}^{-1}\right)$ and aprotinin (Trasylol, Bayer, Leverkusen, Germany) (500 KIU/mL) before and after ETR-P1/fl peptide and NNA infusions, and at the end of the observation period. The blood samples were centrifuged at $1200 \mathrm{~g}$ for $10 \mathrm{~min}$ at $4{ }^{\circ} \mathrm{C}$. The plasma samples were then collected and stored at $-70{ }^{\circ} \mathrm{C}$ until assay. Plasma samples were analyzed for ET-1 with an ELISA kit (Biomedica, Vienna, Austria). According to the manufacturer, the cross-reactivity with ET-1 and ET-2 was $100 \%$.

\section{Plasma nitrite/nitrate level measurements}

The levels of plasma nitrite/nitrate $\left(\mathrm{NO}_{\mathrm{x}}\right)$, stable end-products of $\mathrm{NO}$, were measured by the Griess reaction. The assay depends on the enzymatic reduction of nitrate to nitrite, which was then converted into a colored azo compound detected spectrophotometrically at $540 \mathrm{~nm}$ (Moshage 1995). 


\section{NOS activity measurements}

NO formation in cardiac tissues was measured via the conversion of $\left[{ }^{3} \mathrm{H}\right] \mathrm{L}$-citrulline from $\left[{ }^{3} \mathrm{H}\right] \mathrm{L}$-arginine according to the method of Szabó (1993). Briefly, heart biopsies kept on ice were homogenized in phosphate buffer $(\mathrm{pH}$ 7.4) containing $50 \mathrm{mM}$ Tris- $\mathrm{HCl}, 0.1 \mathrm{mM}$ EDTA, $0.5 \mathrm{mM}$ dithiotreitol, $1 \mathrm{mM}$ phenylmethylsulfonyl fluoride, $10 \mu \mathrm{g} \mathrm{ml}^{-1}$ soybean trypsin inhibitor and $10 \mu \mathrm{g} \mathrm{ml}^{-1}$ leupeptin. The homogenate was centrifuged at $4{ }^{\circ} \mathrm{C}$ for $20 \mathrm{~min}$ at $24,000 \mathrm{~g}$ and the supernatant was loaded into centrifugal concentrator tubes (Amicon Centricon-100; 100,000 MW cut-off ultrafilter). The tubes were centrifuged at $1000 \mathrm{~g}$ for 150 min and the concentrated supernatant was washed out from the ultrafilter with $250 \mu \mathrm{l}$ homogenizing buffer. The samples were incubated with a cation-exchange resin (Dowex AG $50 \mathrm{~W}-\mathrm{X} 8, \mathrm{Na}^{+}$form) for $5 \mathrm{~min}$ to deplete endogenous L-arginine. The resin was separated by centrifugation (1500g for $10 \mathrm{~min}$ ) and the supernatant containing the enzyme was assayed for NOS activity.

For the $\mathrm{Ca}^{2+}$-dependent NOS (cNOS) activity, $50 \mu$ l enzyme extract and $100 \mu \mathrm{l}$

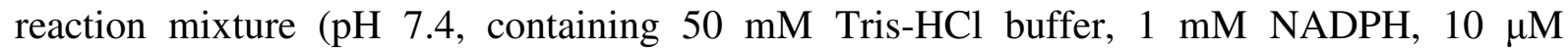
tetrahydrobiopterine, $1.5 \mathrm{mM} \mathrm{CaCl}_{2}, 100 \mathrm{U} \mathrm{ml}^{-1}$ calmodulin and $0.5 \mu \mathrm{Ci}\left[{ }^{3} \mathrm{H}\right] \mathrm{L}$-arginine (Amersham U.K., specific activity $63 \mathrm{Ci} \mathrm{mmol}^{-1}$ )) were incubated together for $60 \mathrm{~min}$ at 37 ${ }^{\circ} \mathrm{C}$. The reaction was stopped by the addition of $1 \mathrm{ml}$ ice-cold HEPES buffer ( $\mathrm{pH} 5.5$ ) containing $2 \mathrm{mM}$ EGTA and $2 \mathrm{mM}$ EDTA. Measurements were performed with the NOS inhibitor NNA $(3.2 \mathrm{mM})$ to determine the extent of $\left[{ }^{3} \mathrm{H}\right] \mathrm{L}$-citrulline formation independent of the NOS activity. $\mathrm{Ca}^{2+}$-independent NOS activity (iNOS) was measured without Cacalmodulin and with EGTA $(8 \mathrm{mM}) .1 \mathrm{ml}$ reaction mixture was applied to Dowex cationexchange resin (AG 50W-X8, $\mathrm{Na}^{+}$form) and eluted with $2 \mathrm{ml}$ distilled water. The eluted $\left[{ }^{3} \mathrm{H}\right] \mathrm{L}$-citrulline activity was measured with a scintillation counter (Tri-Carb Liquid Scintillation Analyzer 2100TR/2300TR, Packard Instrument Co, Meriden, CT, U.S.A.). Protein contents of samples were determined by the Lowry method.

\section{Whole blood superoxide production}

Superoxide production was assessed by the lucigenin-enhanced chemiluminescence assay of Zimmermann et al. (Zimmermann 1991). Briefly, $10 \mu \mathrm{l}$ blood samples were added to $1 \mathrm{ml}$ Hank's balanced solution (PAA Cell Culture Company) at $37{ }^{\circ} \mathrm{C}$. After addition of 100 $\mu \mathrm{l}$ lucigenin $(15 \mu \mathrm{M})$, the chemiluminescence response was measured (as relative light units) over a period of $30 \mathrm{~min}$, using a Lumat LB9507 luminometer (Berthold, Germany). 
Determination of myocardial xanthine oxidoreductase (XOR) activity

Heart biopsies kept on ice were homogenized in phosphate buffer ( $\mathrm{pH}$ 7.4) containing $50 \mathrm{mM}$ Tris- $\mathrm{HCl}, 0.1 \mathrm{mM}$ EDTA, $0.5 \mathrm{mM}$ dithiotreitol, $1 \mathrm{mM}$ phenylmethylsulfonyl fluoride, $10 \mu \mathrm{g} \mathrm{ml}^{-1}$ soybean trypsin inhibitor and $10 \mu \mathrm{g} \mathrm{ml}^{-1}$ leupeptin. The homogenate was centrifuged at $4{ }^{\circ} \mathrm{C}$ for $20 \mathrm{~min}$ at $24,000 \mathrm{~g}$ and the supernatant was loaded into centrifugal concentrator tubes. The activity of XOR was determined in the ultrafiltered supernatant by fluorometric kinetic assay based on the conversion of pterine to isoxanthopterine in the presence (total XOR) or absence (xanthine oxidase activity) of the electron acceptor methylene blue (Beckman 1989).

\section{Myocardial myeloperoxidase (MPO) activity measurement}

The MPO activity, as a marker of tissue polymorphonuclear leukocyte infiltration, was measured via cardiac muscle biopsies (Kuebler 1996). Briefly, the sample was homogenized with Tris-HCl buffer $(0.1 \mathrm{M}, \mathrm{pH} 7.4)$ containing $0.1 \mathrm{mM}$ phenylmethylsulfonyl fluoride to block tissue proteases, and then centrifuged at $4{ }^{\circ} \mathrm{C}$ for $20 \mathrm{~min}$ at $2000 \mathrm{~g}$. The MPO activities of the samples were measured at $450 \mathrm{~nm}$ (UV-1601 spectrophotometer, Shimadzu, Japan) and the data were referred to the protein content.

\subsection{Experimental protocols}

In Study I, the animals were randomly allocated to one or other of three groups. Surgery was followed by a recovery period for cardiovascular stabilization. Baseline variables were determined during a 15 -min control period. Group $1(n=7)$ was treated with $0.9 \%$ saline iv, while in Groups 2 and 3 ( $n=7$ each) the animals received $4 \mathrm{mg} \mathrm{kg}^{-1}$ NNA (Sigma Chem. U.S.A.) in $2 \mathrm{ml} \mathrm{kg}^{-1}$ saline during a 15-min iv infusion. The animals in Group 3 were additionally pretreated (100 nmol kg$~^{-1}$ iv bolus in $1.5 \mathrm{ml} \mathrm{kg}^{-1}$ saline) with the selective ET-A receptor antagonist ETR-P1/fl peptide (VLNLCALSVDRYRAVASWRVI; Kurabo Ltd., Osaka, Japan) (Baranyi 1995, Baranyi 1998) 30 min before NNA treatment. The animals were observed for $135 \mathrm{~min}$ after the end of the treatment period; hemodynamic measurements were performed every $30 \mathrm{~min}$.

In Study II, surgery was followed by a recovery period for cardiovascular stabilization, and baseline variables were then determined during a 30-min control period. The animals were randomly allocated to one or other of three groups. Group $4(n=10)$, which as control, was treated with $0.9 \%$ saline $\left(4 \mathrm{ml} \mathrm{kg}^{-1}\right)$, while Groups $5(n=7)$ and $6(n=7)$ were infused iv with $4 \mathrm{ml} \mathrm{kg}^{-1} \mathrm{HSD}$ during $15 \mathrm{~min}$. The solution was prepared from isotonic $10 \%$ dextran-40 (Baxter, Munich, Germany) and 7.2\% $\mathrm{NaCl}$ solution. The animals in Group 6 were additionally treated with $4 \mathrm{mg} \mathrm{kg}^{-1} \mathrm{NNA}$ (Sigma Chem. U.S.A.) in $2 \mathrm{ml} \mathrm{kg}^{-1}$ saline during a 5- 
min iv infusion 15 min before HSD treatment. The beginning of HSD infusion served as the zero point of the experiments, and the animals were observed for a further $120 \mathrm{~min}$ in all groups.

\subsection{Statistical analysis}

Data analysis was performed with a statistical software package (SigmaStat for Windows, Jandel Scientific, Erkrath, Germany). Nonparametric methods were used. Friedman repeated measures analysis of variance on ranks was applied within the groups. Timedependent differences from the baseline (time 0) for each group were assessed by Dunn's method, and differences between groups were analyzed with Kruskal-Wallis one-way analysis of variance on ranks, followed by Dunn's method for pairwise multiple comparison. In the Figures and Table 1 , median values and 75th and 25 th percentiles are given. $P$ values $<0.05$ were considered significant. 


\section{RESULTS}

\subsection{Study I: Cardiac and peripheral effects of NNA treatment}

\section{Initial effects of surgery}

In the Group 1, there were no significant hemodynamic changes as compared with the baseline values, and the plasma $\mathrm{NO}_{\mathrm{x}}$ and ET-1 levels did not change significantly during the 180-min observation period.

\section{Hemodynamic effects of NNA infusion}

The infusion of $4 \mathrm{mg} / \mathrm{kg}$ NNA resulted in sustained increases in MAP (Figure 1) and CVP (data not shown). Nonspecific NOS inhibition caused an approximately $25 \%$ decrease in CI (Figure 2), parallel with a gradual decrease in heart rate (HR) (Figure 3). The total peripheral vascular resistance (TPR) was increased nearly 2-fold as compared with the baseline values 105 min after NNA treatment (Figure 4).

Nonspecific NOS inhibition significantly reduced the difference between the LV diastolic and systolic diameters (as a percentage of the baseline) (Figure 5) and caused a significant increase in myocardial contractility up to the end of the observation period (Figure $6)$.

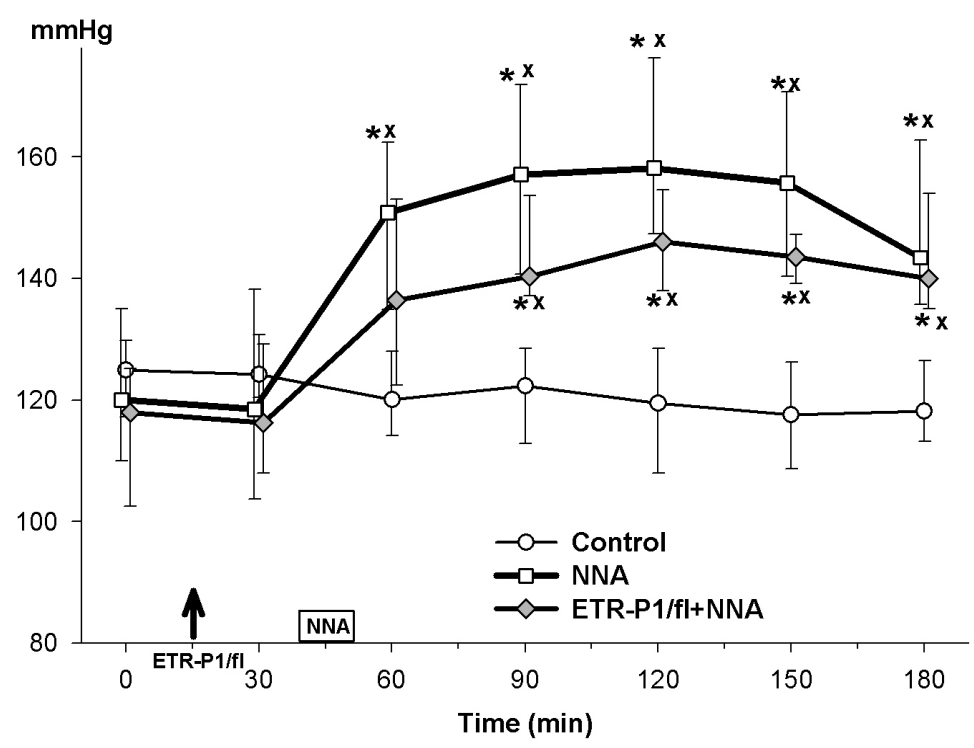

Figure 1. Changes in MAP in the control group (Group 1; circles), the NNA-treated group (squares) and the ETR-P1/fl+NNA-treated group (diamonds). Data are expressed as medians $\pm 25^{\text {th }}$ and $75^{\text {th }}$ percentiles. ${ }^{*} P<0.05$ within group; ${ }^{\mathrm{X}} P<0.05$ between groups $v s$ salinetreated control group values, ${ }^{\#} P<0.05$ between groups $v s$ NNA-treated group values. 


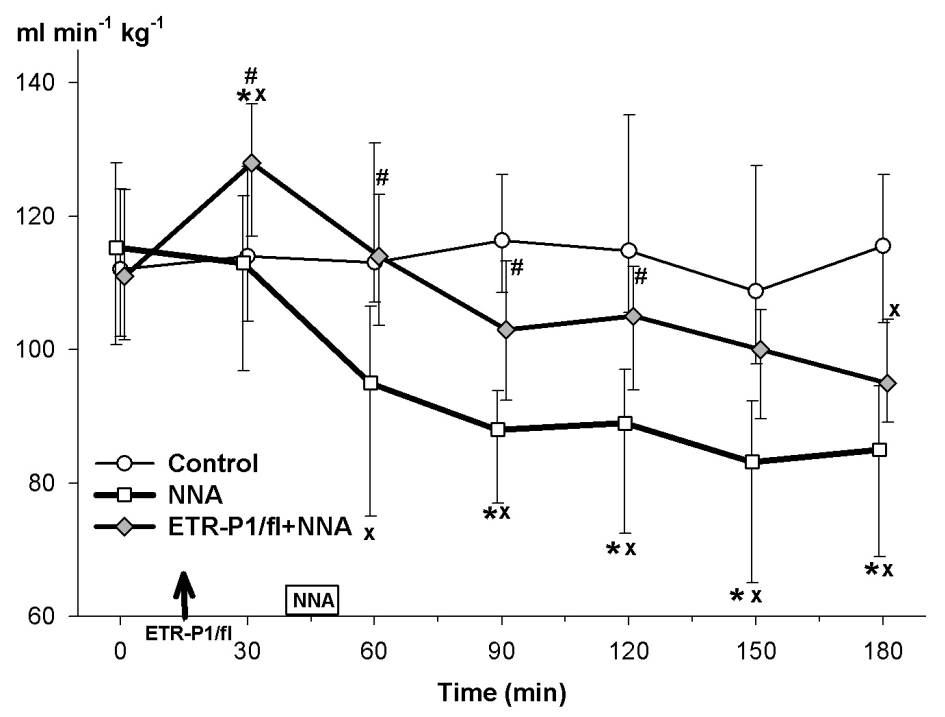

Figure 2. Changes in $\mathrm{CI}$ in the control group (Group 1; circles), the NNA-treated group (squares) and the ETR-P1/fl+NNA-treated group (diamonds). Data are expressed as medians $\pm 25^{\text {th }}$ and $75^{\text {th }}$ percentiles. $* P<0.05$ within group; ${ }^{\mathrm{X}} P<0.05$ between groups $v s$ salinetreated control group values, ${ }^{\#} P<0.05$ between groups $v s$ NNA-treated group values.

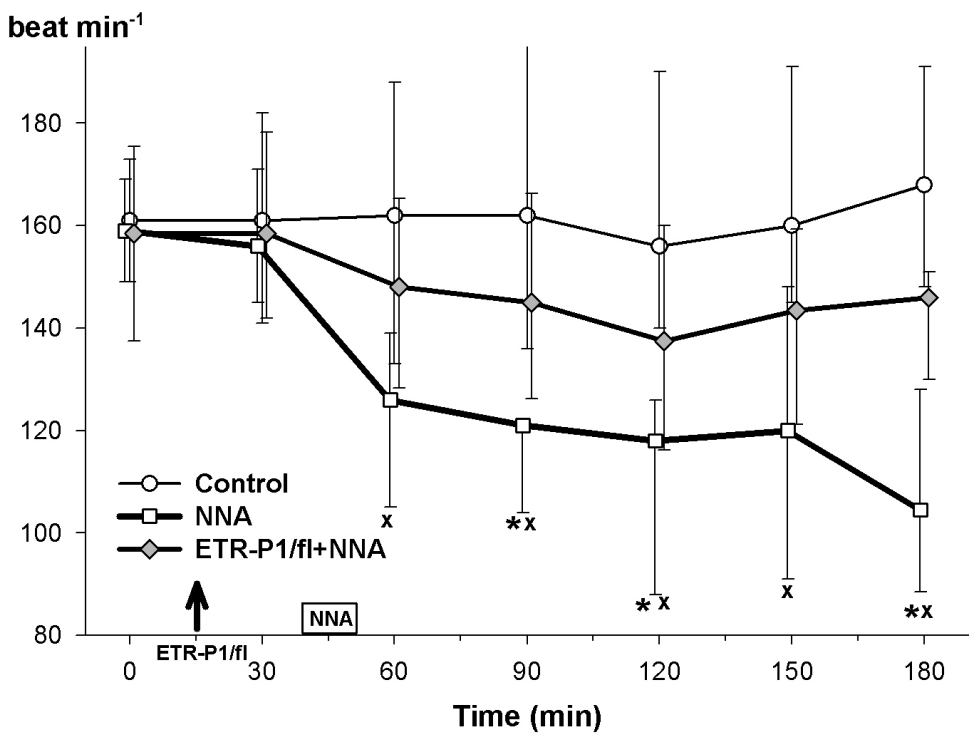

Figure 3. Changes in HR in the control group (Group 1; circles), the NNA-treated group (squares) and the ETR-P1/fl+NNA-treated group (diamonds). Data are expressed as medians $\pm 25^{\text {th }}$ and $75^{\text {th }}$ percentiles. $* P<0.05$ within group; ${ }^{\mathrm{X}} P<0.05$ between groups $v s$ salinetreated control group values, ${ }^{\#} P<0.05$ between groups $v s$ NNA-treated group values. 


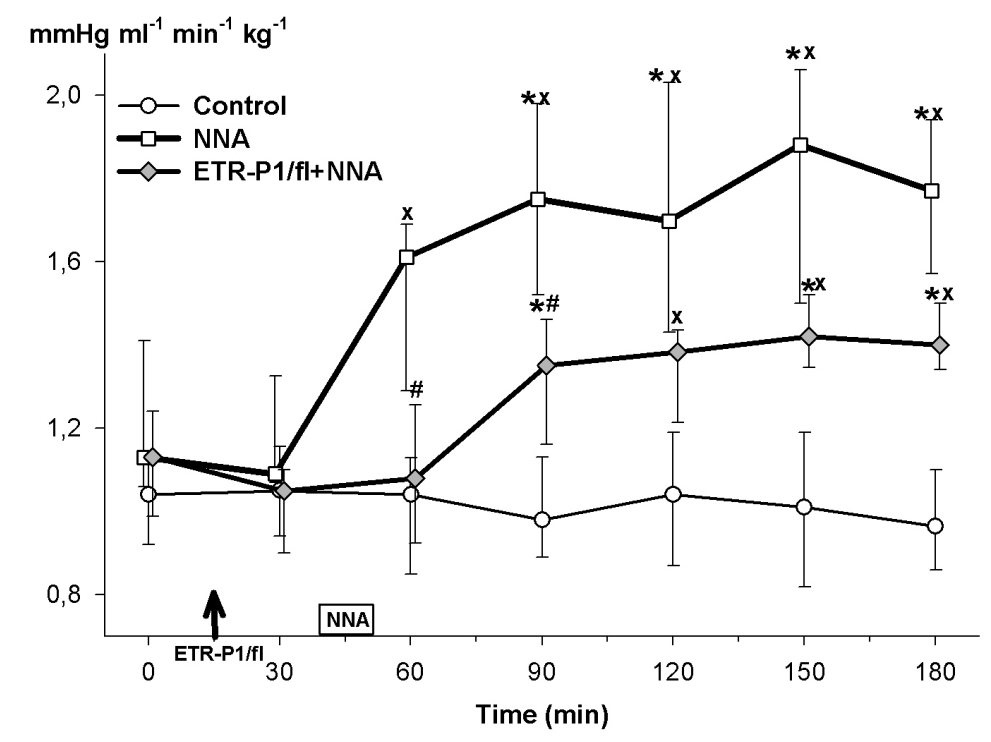

Figure 4. Changes in TPR in the control group (Group 1; circles), the NNA-treated group (squares) and the ETR-P1/fl+NNA-treated group (diamonds). Data are expressed as medians $\pm 25^{\text {th }}$ and $75^{\text {th }}$ percentiles. $* P<0.05$ within group; ${ }^{\mathrm{X}} P<0.05$ between groups $v s$ salinetreated control group values, ${ }^{\#} P<0.05$ between groups $v s$ NNA-treated group values.

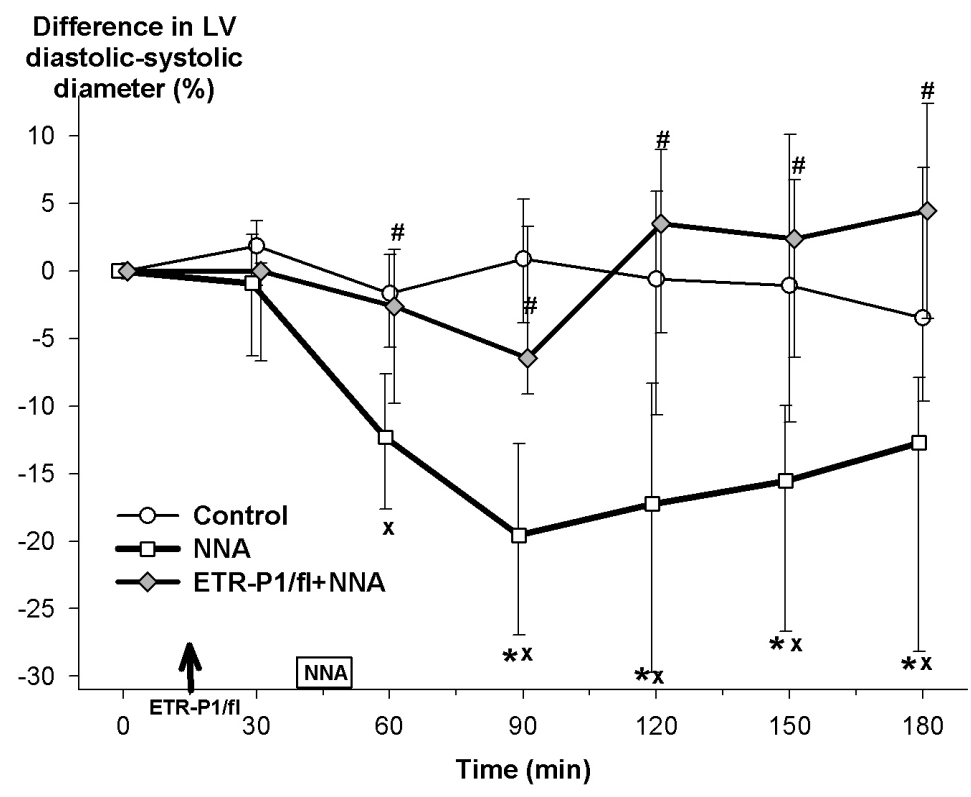

Figure 5. Changes in LV diastolic-systolic diameter difference in the control group (Group 1; circles), the NNA-treated group (squares) and the ETR-P1/fl + NNA-treated group (diamonds). $* P<0.05$ within group; ${ }^{\mathrm{X}} P<0.05$ between groups $v s$ saline-treated control group values; ${ }^{\#} P<0.05$ between groups vs NNA-treated group values. 


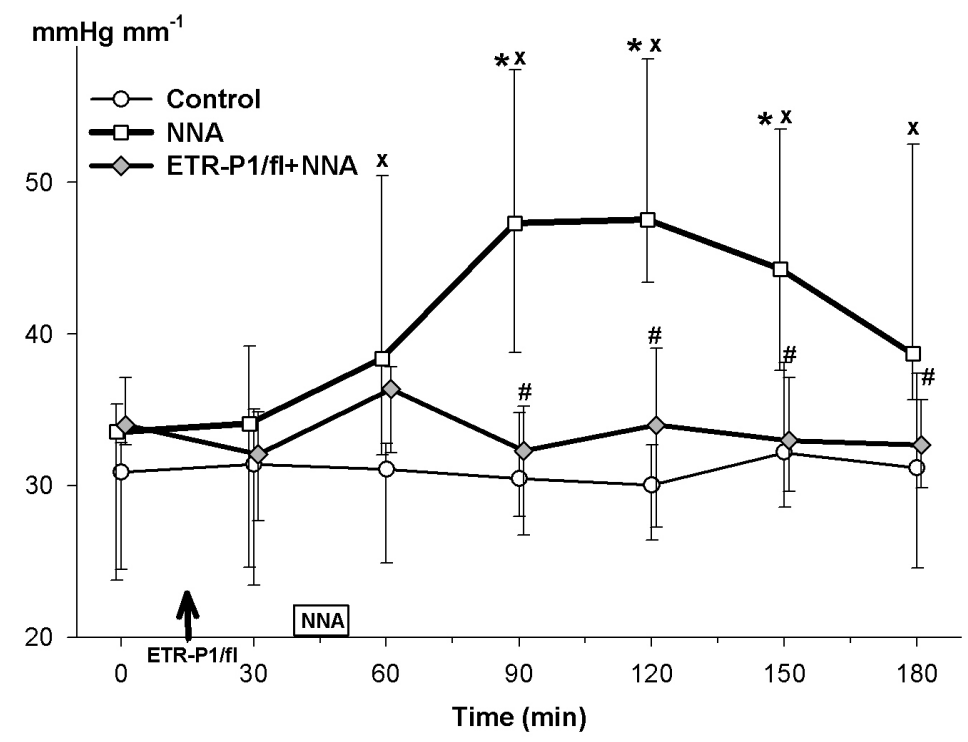

Figure 6. Changes in myocardial contractility in the control group (Group 1; circles), the NNA-treated group (squares) and the ETR-P1/fl + NNA-treated group (diamonds). ${ }^{*} P<0.05$ within group; ${ }^{\mathrm{X}} P<0.05$ between groups $v s$ saline-treated control group values; ${ }^{\#} P<0.05$ between groups vs NNA-treated group values.

\section{Hemodynamic effects of endothelin-A receptor antagonist pretreatment}

The ETR-P1/fl peptide pretreatment mitigated the NNA-induced MAP and CVP elevations, but the differences between the values for the NNA and ETR-P1/fl peptide+NNA groups were statistically not significant (Figure 1). The cardiac effects of ET-A receptor antagonist pretreatment included an immediate, significant increase in CI at $30 \mathrm{~min}$ of the experiment, and the NNA-induced CI decrease was then significantly reduced (Figure 2). The pretreatment mitigated the NNA-induced decrease in HR, but the difference between the NNA and ETR-P1/fl peptide+NNA groups was statistically not significant (Figure 3). The pretreatment effectively antagonized the NOS inhibition-induced TPR elevation in the first 60 min after NNA administration (Figure 4).

However, ETR-P1/fl peptide pretreatment significantly inhibited the NNA-induced decrease in the LV diastolic-systolic diameter difference (Figure 5) and the NNA-induced elevation in myocardial contractility (Figure 6).

\section{$\underline{\text { Biochemical changes in blood and myocardial tissue }}$}

The plasma ET-1 concentration gradually rose to approximately 1.5-fold following NNA infusion and remained significantly higher than in the control group (Group 1) up to $120 \mathrm{~min}$ in the observation period (Figure 7). The NOS inhibitor treatment caused a 
significant decrease in plasma $\mathrm{NO}_{\mathrm{x}}$ level at 90 min (Figure 8). Concomitantly, an approx. 5fold increase in blood superoxide production was observed (Figure 9).

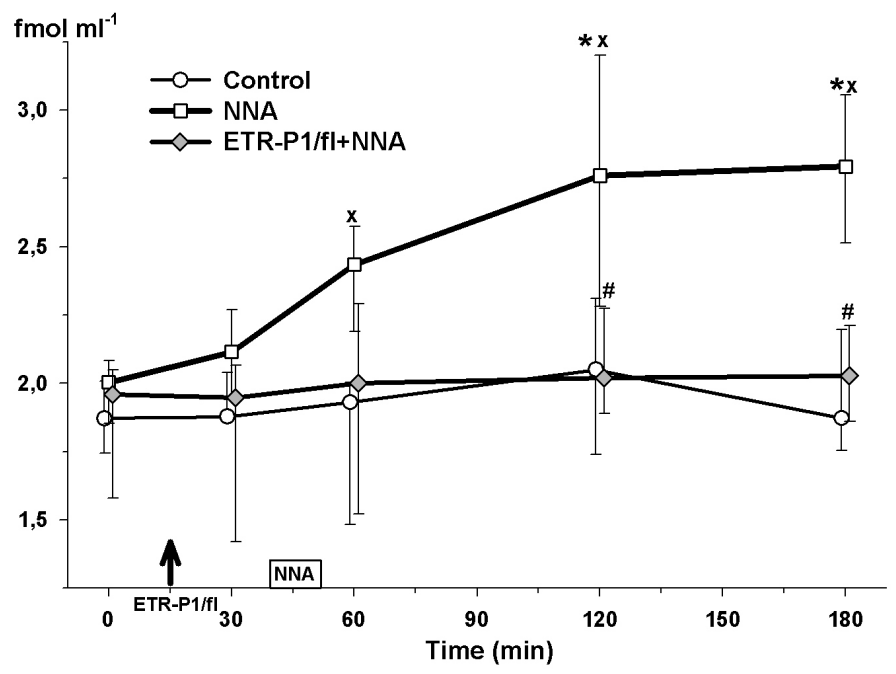

Figure 7. Changes in plasma ET-1 level in the control group (Group 1; circles), the NNAtreated group (squares) and the ETR-P1/fl+NNA-treated group (diamonds). $* P<0.05$ within group; ${ }^{\mathrm{X}} P<0.05$ between groups vs saline-treated control group values; ${ }^{\#} P<0.05$ between groups $v s$ NNA-treated group values.

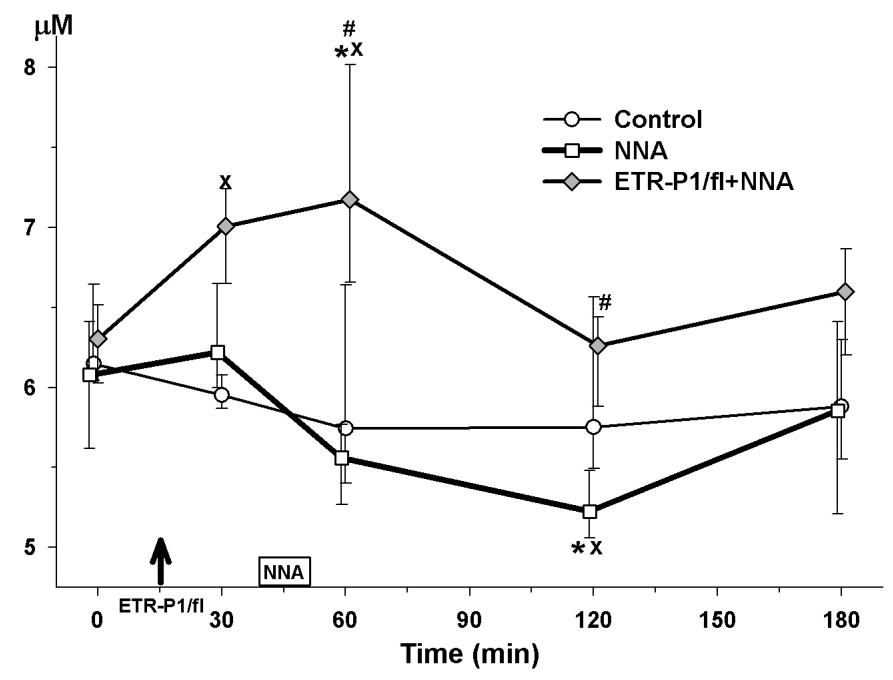

Figure 8. Changes in plasma $\mathrm{NO}_{\mathrm{x}}$ level in the control group (Group 1; circles), the NNAtreated group (squares) and the ETR-P1/fl+NNA-treated group (diamonds). $* P<0.05$ within group; ${ }^{\mathrm{X}} P<0.05$ between groups $v s$ saline-treated control group values; ${ }^{\#} P<0.05$ between groups $v s$ NNA-treated group values. 


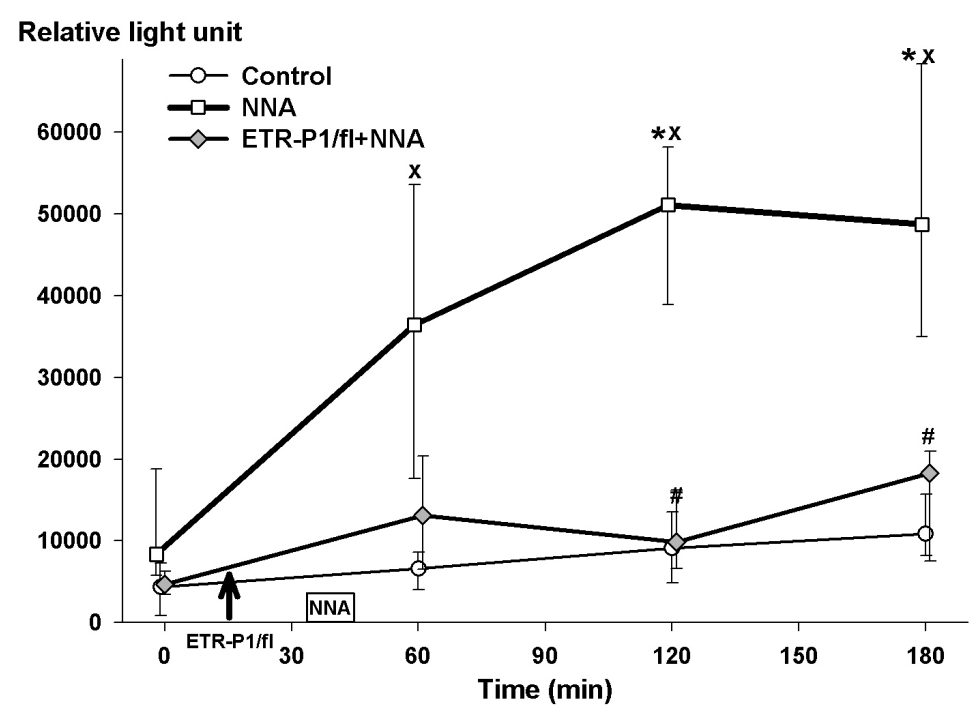

Figure 9. Changes in superoxide production of whole blood in the control group (Group 1; circles), the NNA-treated group (squares) and the ETR-P1/fl+NNA-treated group (diamonds). * $P<0.05$ within group; ${ }^{X} P<0.05$ between groups $v s$ saline-treated control group values; ${ }^{\#} P<0.05$ between groups vs NNA-treated group values.

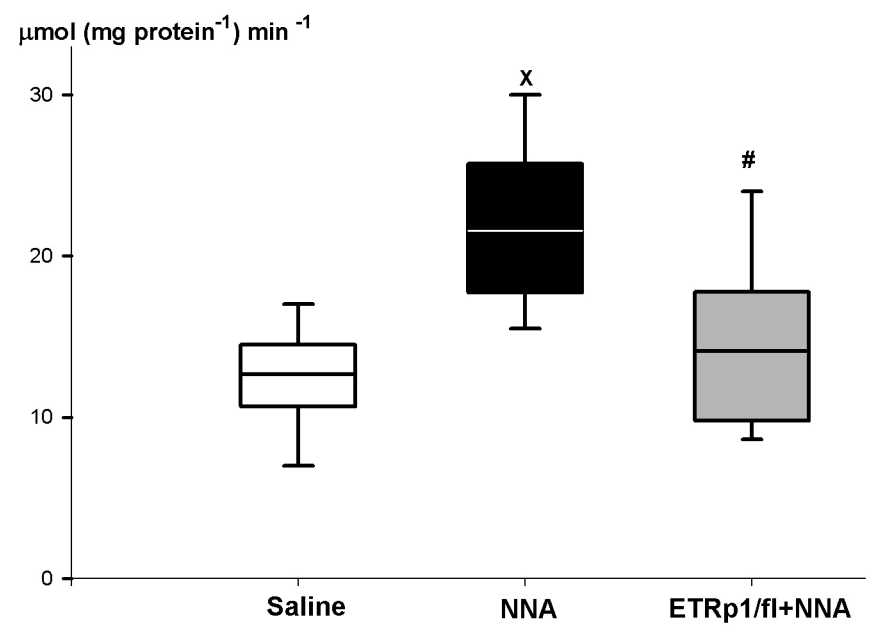

Figure 10. XOR activities in myocardial tissue $135 \mathrm{~min}$ after treatment in the saline-treated control group (empty box), the NNA-treated group (black box) and the ETR-P1/fl peptide+NNA-treated group (gray box) animals. The plots demonstrate the median values and the $25^{\text {th }}$ (lower whisker) and $75^{\text {th }}$ (upper whisker) percentiles. ${ }^{\mathrm{X}} P<0.05$ between groups $v s$ saline-treated control group values. ${ }^{\#} P<0.05$ between NNA-treated and ETR-P1/fl peptide+NNA-treated group values. 
The ETR-P1/fl peptide pretreatment prevented the NNA-induced increase in plasma ET-1 level throughout the observation period (Figure 7) and significantly inhibited the NNAinduced superoxide production in the blood (Figure 9). The plasma $\mathrm{NO}_{\mathrm{x}}$ level was significantly higher following the ETR-P1/fl peptide pretreatment until the end of the observation period as compared with the NNA-only group (Figure 8).

The myocardial XOR activity was significantly elevated 135 min after NNA treatment as compared with the control group (Figure 10). The ET-A antagonist pretreatment prevented this late consequence of the NNA infusion.

\subsection{Study II: Early and late effects of nitric oxide on small-volume resuscitation}

The concentration of the HSD solution and the optimal conditions for the volume expander protocol were determined in pilot studies (data not shown). In the control group (Group 4), there were no significant hemodynamic changes as compared with the baseline values, and the mediator level did not change significantly during the120-min observation period.

\section{Hemodynamic effects of HSD infusion with or without NNA treatment}

The HSD-induced peripheral circulatory reaction was characterized by transient MAP and CVP increases (Figure 11 and Table 1) and a biphasic change in TPR: an initial decrease was followed by a return to the baseline during the early phase of the postinfusion period, and the TPR was significantly elevated at $120 \mathrm{~min}$ in the postinfusion period (Figure 12). NNA pretreatment significantly elevated the MAP before HSD infusion, but there was no significant difference between the two HSD-infused groups (Figure 11). This pretreatment caused significant, long-lasting elevations in CVP and TPR relative to the HSD and control groups (Table 1 and Figure 12).

Table 1. Effects of saline, HSD or NNA+HSD pretreatment on CVP $(\mathrm{mmHg}) ; * P<0.05$ within group; ${ }^{\mathrm{X}} P<0.05$ between groups vs saline-treated control group values; ${ }^{\#} P<0.05$ between groups vs HSD-treated group values.

\begin{tabular}{|c|c|c|c|c|c|c|}
\hline & $-30 \min$ & $-1 \min$ & $15 \mathrm{~min}$ & $30 \mathrm{~min}$ & $60 \mathrm{~min}$ & $120 \mathrm{~min}$ \\
\hline $\begin{array}{l}\text { Control } \\
\text { Median } \\
25 \mathrm{p}, 75 \mathrm{p} \\
\end{array}$ & $\begin{array}{c}1.5 \\
1.1 ; 2.0\end{array}$ & $\begin{array}{c}1.7 \\
1.4 ; 2.1\end{array}$ & $\begin{array}{c}1.9 \\
1.6 ; 2.4\end{array}$ & $\begin{array}{c}1.9 \\
1.4 ; 2.6^{*}\end{array}$ & $\begin{array}{c}2.0 \\
1.7 ; 2.6\end{array}$ & $\begin{array}{c}1.8 \\
1.5 ; 2.5\end{array}$ \\
\hline $\begin{array}{c}\text { HSD } \\
\text { Median } \\
25 \mathrm{p}, 75 \mathrm{p} \\
\end{array}$ & $\begin{array}{c}1.7 \\
1.3 ; 2.1\end{array}$ & $\begin{array}{c}1.9 \\
1.7 ; 2.1\end{array}$ & $\begin{array}{c}3.8^{*} \mathrm{x} \\
3.6 ; 4.1\end{array}$ & $\begin{array}{c}2.9^{*} \\
2.4 ; 3.6\end{array}$ & $\begin{array}{c}2.4 \\
2.1 ; 3.1\end{array}$ & $\begin{array}{c}2.2 \\
2.0 ; 2.5\end{array}$ \\
\hline $\begin{array}{c}\text { NNA+HSD } \\
\text { Median } \\
25 \mathrm{p}, 75 \mathrm{p} \\
\end{array}$ & $\begin{array}{c}1.4 \\
1.2 ; 1.9\end{array}$ & $\begin{array}{c}3.3 \\
1.7 ; 3.5\end{array}$ & $\begin{array}{c}5.9^{* \mathrm{x \#}} \\
4.1 ; 5.4\end{array}$ & $\begin{array}{c}4.7^{* \mathrm{X \#}} \\
4.1 ; 5.4\end{array}$ & $\begin{array}{c}4.1^{* \mathrm{x} \#} \\
3.4 ; 5.1\end{array}$ & $\begin{array}{c}4.0^{* \mathrm{X} \#} \\
3.1 ; 4.4\end{array}$ \\
\hline
\end{tabular}




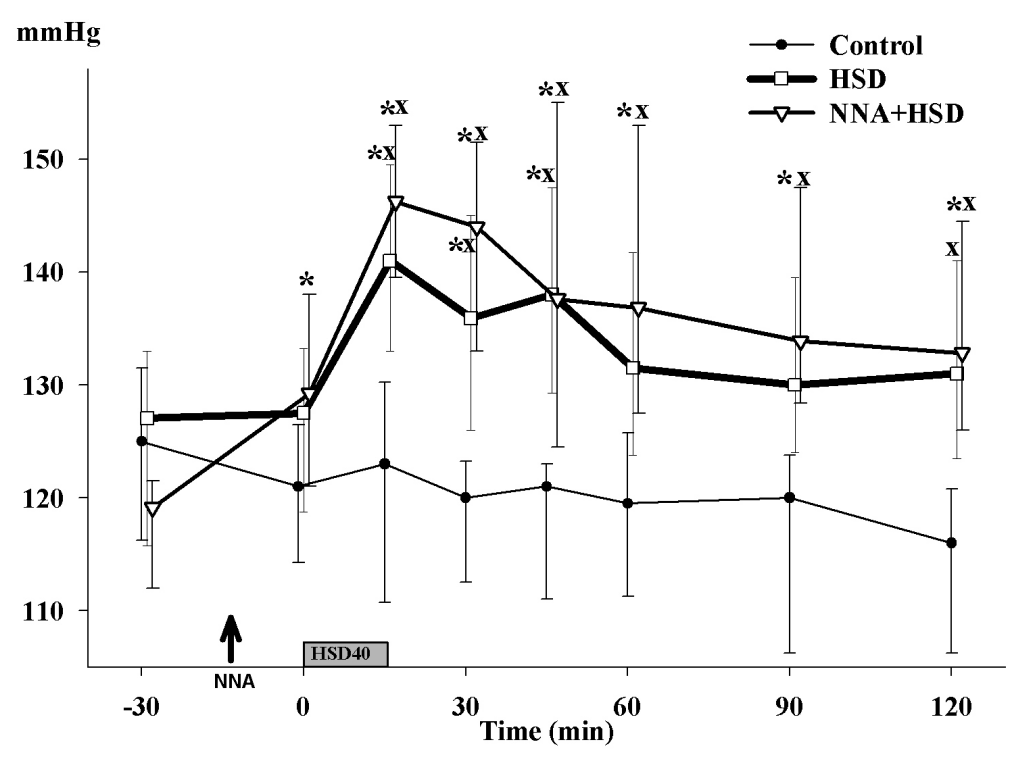

Figure 11. Changes in MAP in the saline-treated control group (Group 4; circles), the HSDtreated group (squares) and the NNA+HSD treated group (triangles). $* P<0.05$ within group; ${ }^{\mathrm{x}} P<0.05$ between groups $v s$ saline-treated control group values.

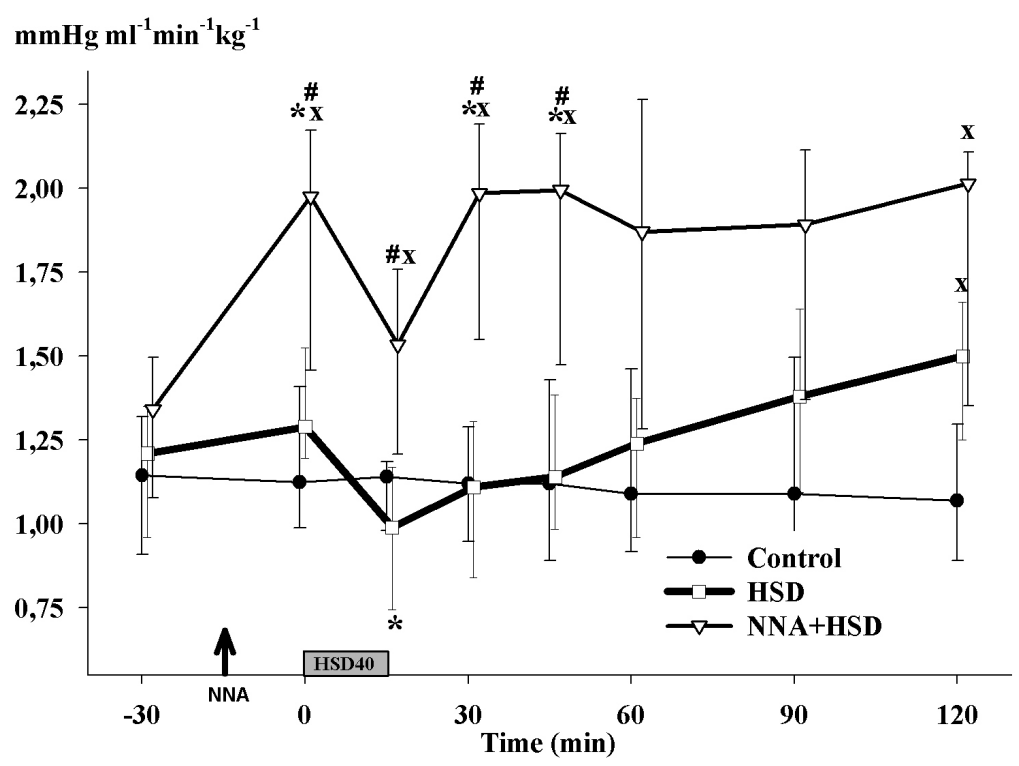

Figure 12. Changes in TPR in the saline-treated control group (Group 4; circles), the HSDtreated group (squares) and the NNA+HSD treated group (triangles). $* P<0.05$ within group; ${ }^{\mathrm{X}} P<0.05$ between groups $v s$ saline-treated control group values; ${ }^{\#} P<0.05$ between groups $v s$ HSD-treated group values.

The cardiac consequences of the HSD-induced volume loading included a significant increase in CI (Figure 13), together with a gradually elevated HR (Figure 14). HSD caused a marked and significant elevation in coronary blood flow too (Figure 15). HSD infusion 
significantly increased the LVD and myocardial contractility until $60 \mathrm{~min}$ of the postinfusion period (Figures 16 and 17).

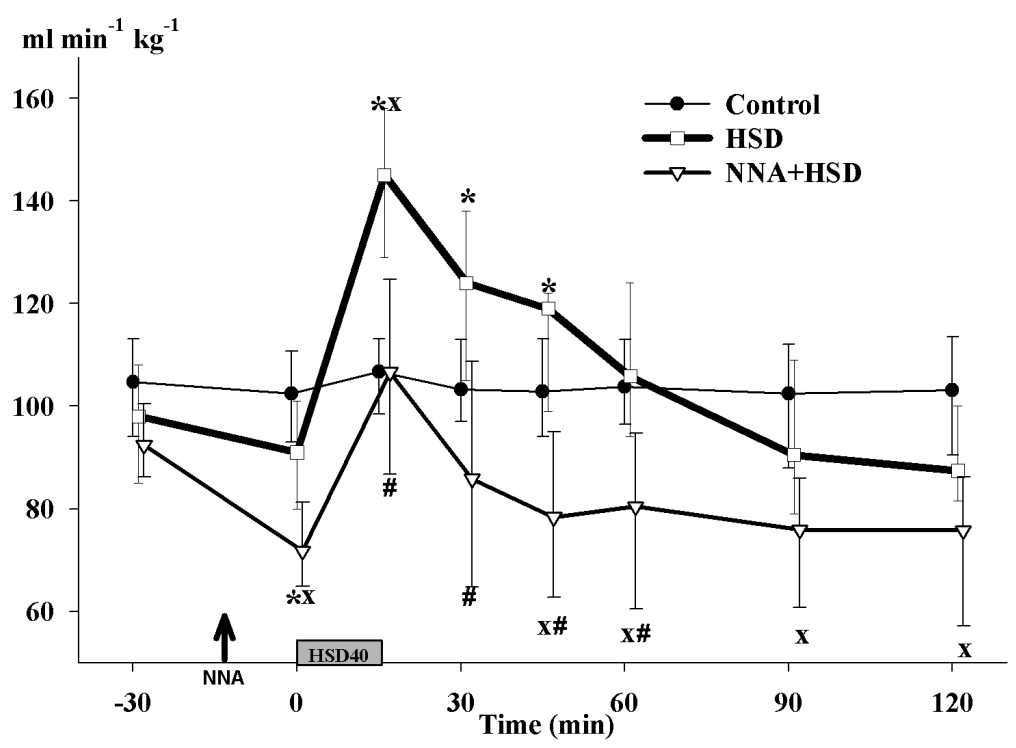

Figure 13. Changes in CI in the saline-treated control group (Group 4; circles), the HSDtreated group (squares) and the NNA+HSD treated group (triangles). $* P<0.05$ within group; ${ }^{\mathrm{X}} P<0.05$ between groups $v s$ saline-treated control group values; ${ }^{\#} P<0.05$ between groups $v s$ HSD-treated group values.

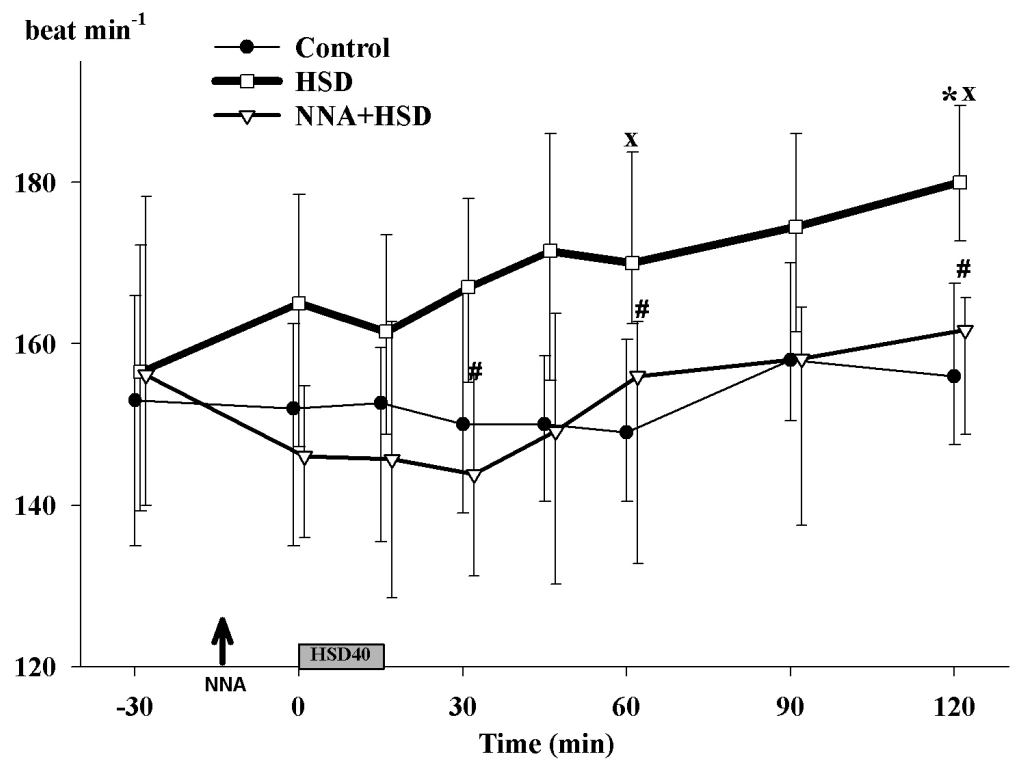

Figure 14. Changes in HR in the saline-treated control group (Group 4; circles), the HSDtreated group (squares) and the NNA+HSD treated group (triangles). $* P<0.05$ within group; ${ }^{\mathrm{X}} P<0.05$ between groups $v s$ saline-treated control group values; ${ }^{\#} P<0.05$ between groups $v s$ HSD-treated group values. 
The NNA pretreatment immediately decreased the CI before HSD infusion and significantly inhibited the HSD-induced CI elevation for $60 \mathrm{~min}$ (Figure 13). This treatment resulted in a lower HR as compared with the HSD infusion, especially in the postinfusion phase (Figure 14). Nonselective NOS inhibition decreased the HSD-induced coronary flow elevation (Figure 15). The preload index LVD did not differ significantly from the result in the HSD-only group, but the late effect of the NNA treatment was a noteworthy decrease as a percentage of LVD (Figure 16).

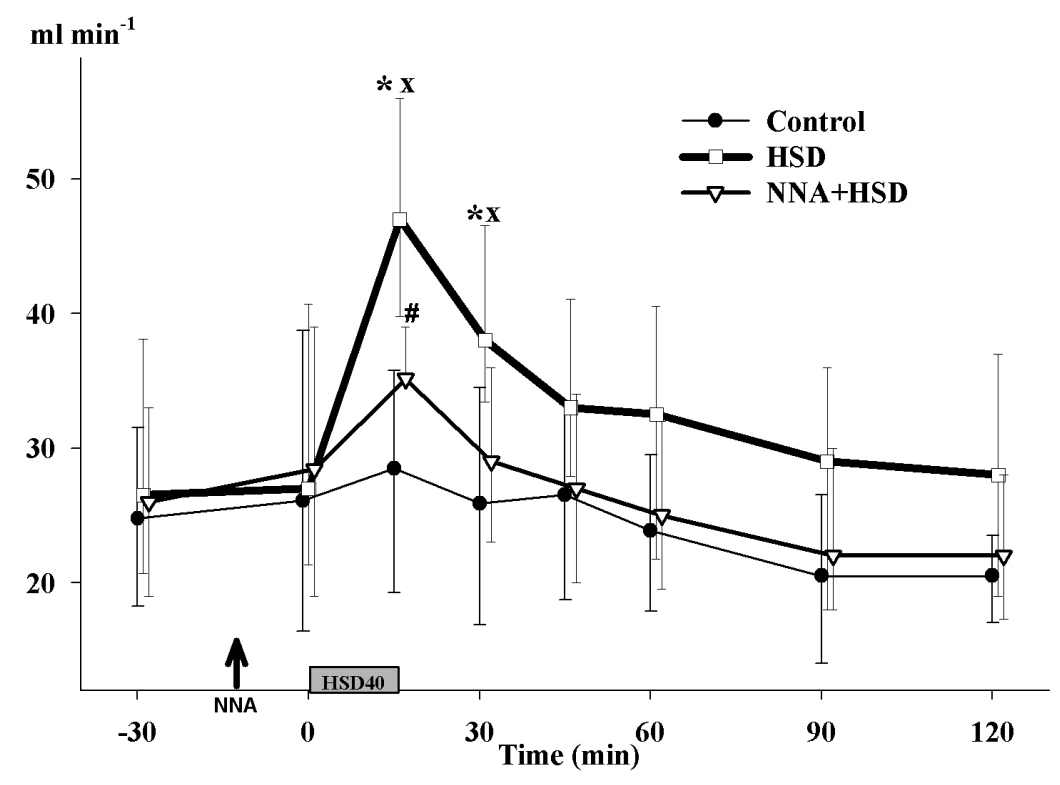

Figure 15. Changes in coronary flow in the saline-treated control group (Group 4; circles), the HSD-treated group (squares) and the NNA+HSD-treated group (triangles). ${ }^{*} P<0.05$ within group; ${ }^{\mathrm{X}} P<0.05$ between groups $v s$ saline-treated control group values; ${ }^{\#} P<0.05$ between groups vs HSD-treated group values.

The cardiac contractility showed a biphasic reaction under this experimental protocol: NNA treatment immediately increased the end-systolic pressure-diameter relationship before volume loading, but the HSD-induced positive inotropy was decreased significantly until 60 min after HSD infusion and gradually increased again in the late phase of the postinfusion period (Figure 17). 


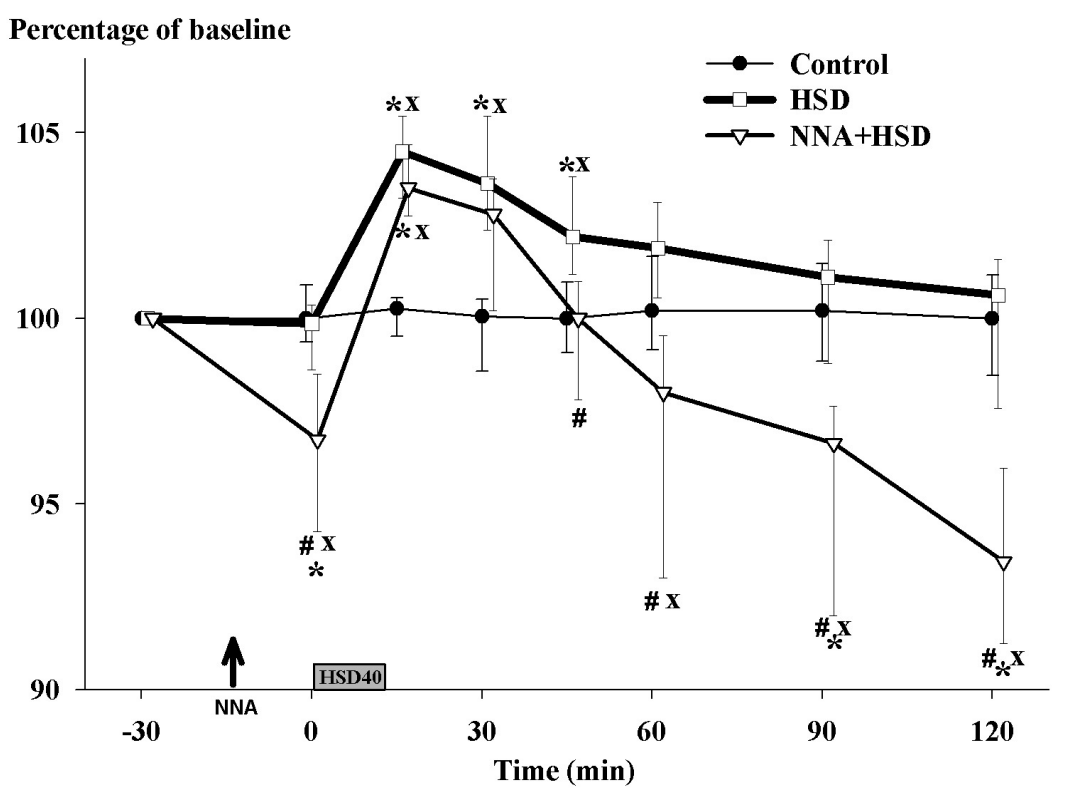

Figure 16. Changes in diastolic LVD in the saline-treated control group (Group 4; circles), the HSD-treated group (squares) and the NNA+HSD-treated group (open triangles). * $P<0.05$ within group; ${ }^{\mathrm{X}} P<0.05$ between groups $v s$ saline-treated control group values; ${ }^{\#} P<0.05$ between groups $v s$ HSD-treated group values.

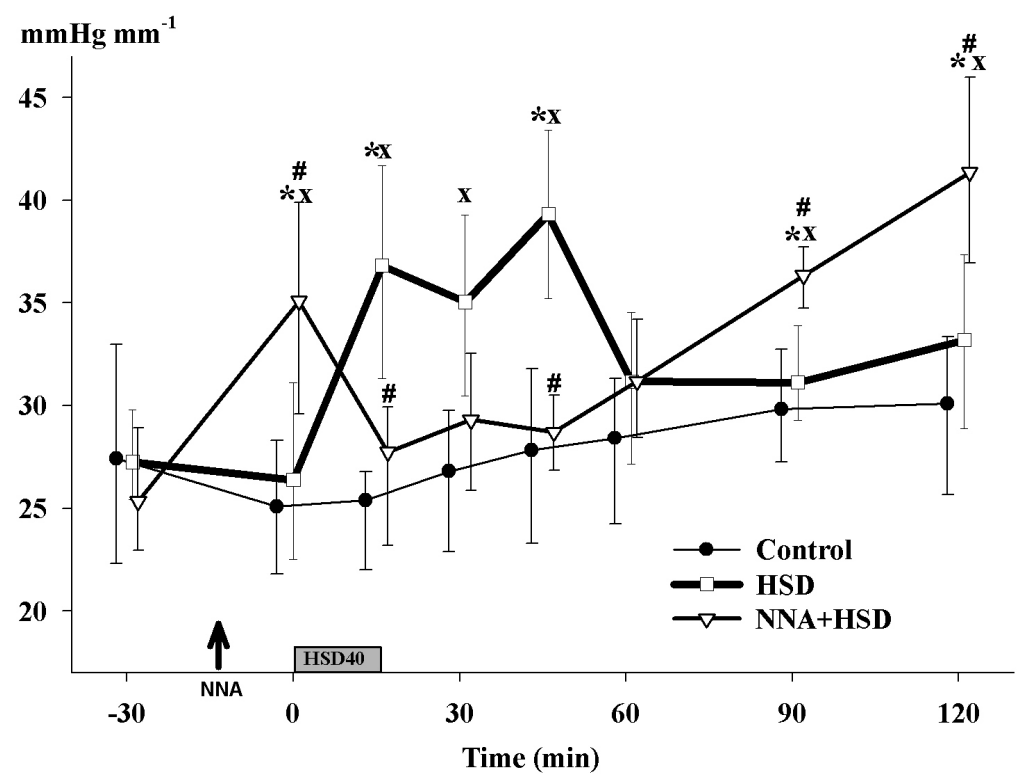

Figure 17. Changes in myocardial contractility in the saline-treated control group (Group 4; circles), the HSD-treated group (squares) and the NNA+HSD-treated group (triangles). ${ }^{*} P<0.05$ within group; ${ }^{\mathrm{X}} P<0.05$ between groups $v s$ saline-treated control group values; ${ }^{\#} P<0.05$ between groups vs HSD-treated group values. 


\section{Biochemical changes in blood and myocardial tissue}

The plasma ET-1 concentration was significantly increased (approximately 1.5-fold) by the end of the infusion (HSD group: 3.09 $\pm 0.21 v s$ control Group 4: $1.72 \pm 0.11 \mathrm{fmol} \mathrm{ml}^{-1}$ ), and remained significantly higher than in the control Group 4 up to the end of the 120-min observation period (Figure 18). Concomitantly, the HSD infusion caused a transient and significant, 45-min elevation in plasma $\mathrm{NO}_{\mathrm{x}}$ level (Figure 19). The NNA pretreatment significantly enhanced the HSD-induced increase in plasma ET-1 level throughout the whole observation period as compared with the HSD-only group (Figure 18), while a lowered level of the plasma $\mathrm{NO}_{\mathrm{x}}$ was detected in the course of the postinfusion period (Figure 19).

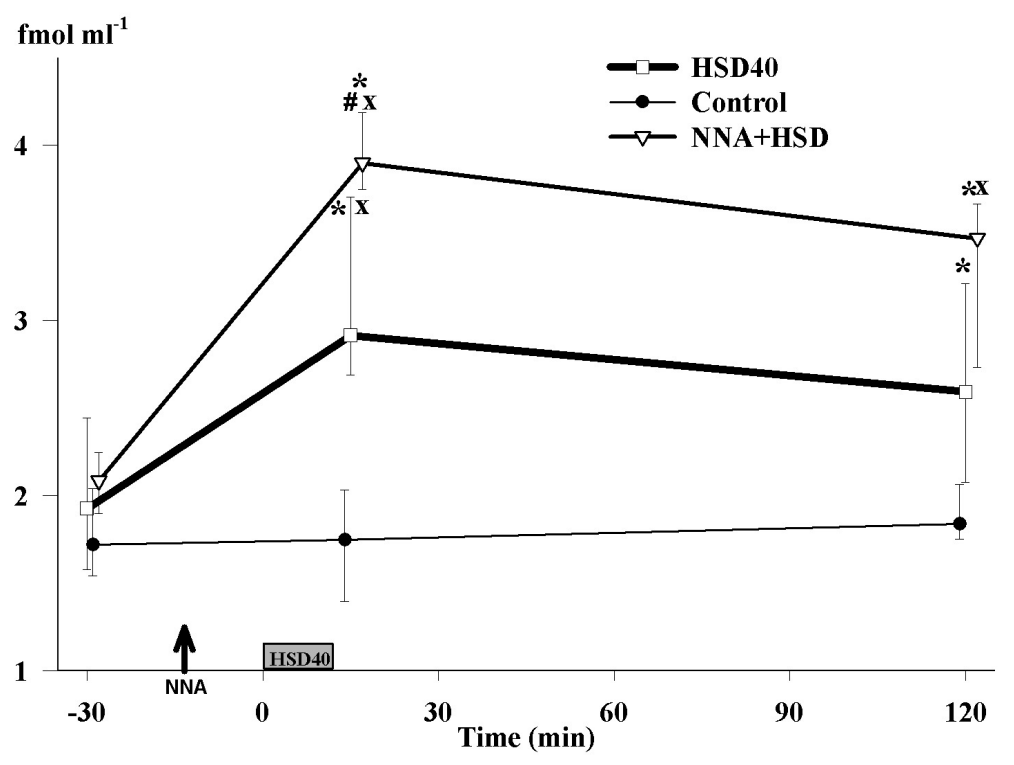

Figure 18. Changes in plasma ET-1 level in the saline-treated control group (Group 4; circles), the HSD-treated group (squares) and the NNA+HSD treated group (triangles). ${ }^{*} P<0.05$ within group; ${ }^{\mathrm{X}} P<0.05$ between groups $v s$ saline-treated control group values; ${ }^{\#} P<0.05$ between groups $v s$ HSD-treated group values.

However, $120 \mathrm{~min}$ after the HSD infusion, the myocardial cNOS activity was significantly lower as compared with that in the control Group 4 (Figure 20A). In these biopsies, the tissue MPO activity was significantly increased relative to the control Group 4 (Figure 20B). The nonselective NOS inhibitor pretreatment lowered the HSD-induced decrease in myocardial cNOS activity more appreciable by the end of the postinfusion period, but the NOS values were not significantly different from those in the HSD group (Figure 20A). The administration of NNA increased the myocardial MPO activity, but the differences were not statisticaly significant in MPO activity between the HSD-only group and the NNApretreated groups. 


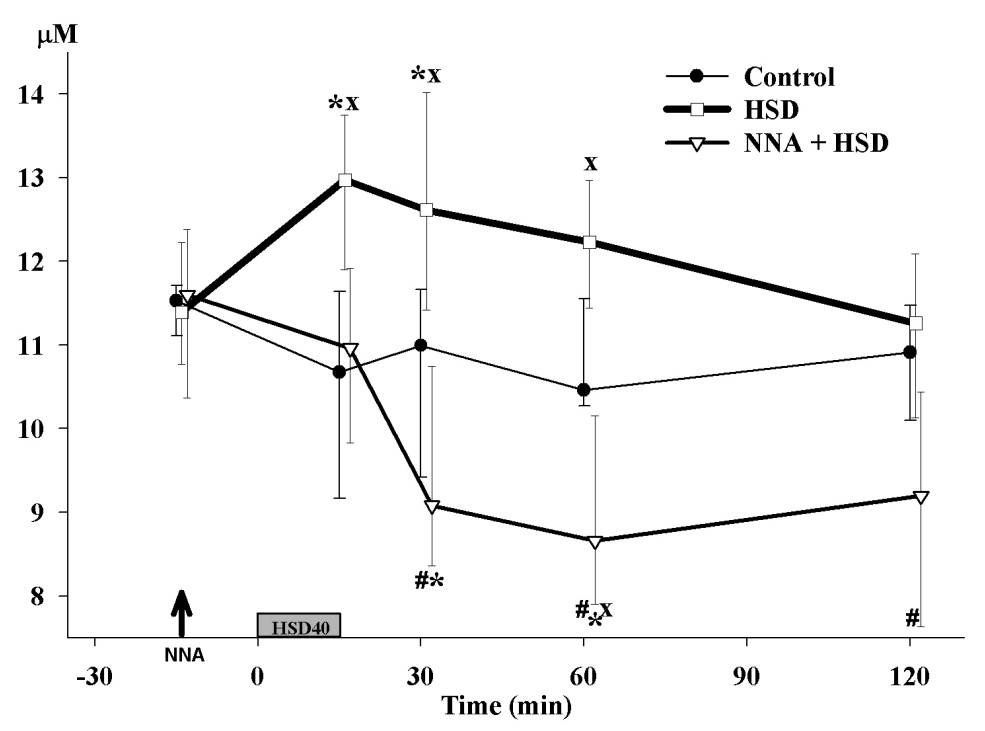

Figure 19. Changes in plasma $\mathrm{NO}_{\mathrm{x}}$ level in the saline-treated control group (Group 4; circles), the HSD-treated group (squares) anf the NNA+HSD treated group (triangles). ${ }^{*} P<0.05$ within group; ${ }^{\mathrm{X}} P<0.05$ between groups $v s$ saline-treated control group values; ${ }^{\#} P<0.05$ between groups $v s$ HSD-treated group values.
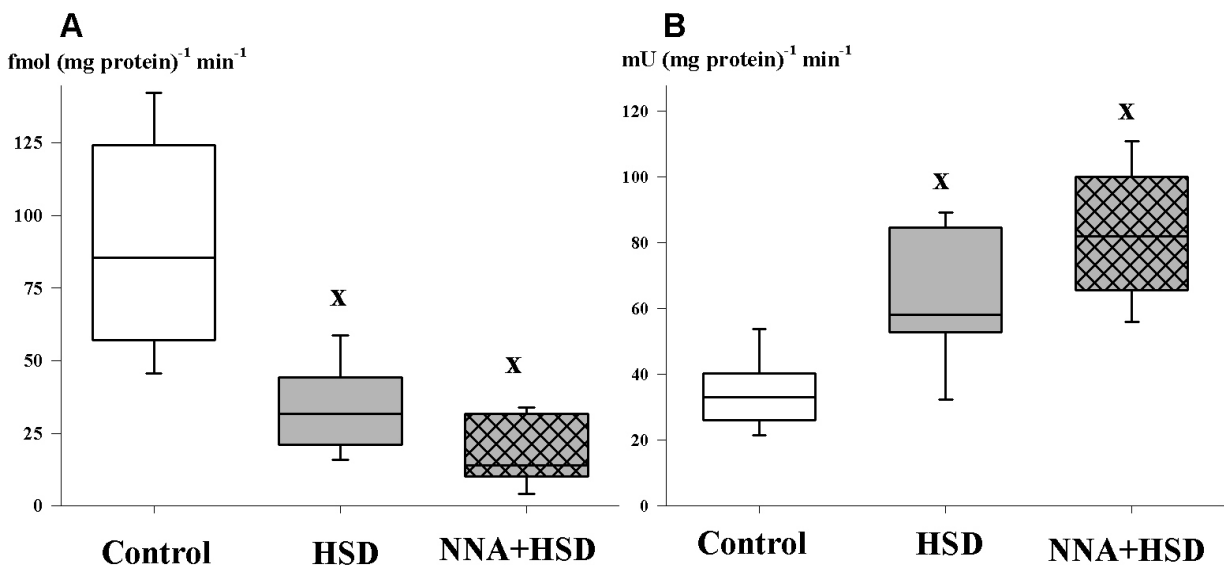

Figure 20. cNOS activities (A) and myocardial MPO activities (B) in myocardial tissue 120 min after treatment in the saline-treated (empty box), the HSD-treated (gray box) and the NNA-treated (checked box) animals. ${ }^{\mathrm{X}} P<0.05$ between groups $v s$ saline-treated control group values. ${ }^{\#} P<0.05$ between groups $v s$ HSD-treated group values. 


\section{DISCUSSION}

\subsection{Discussion of Study I}

Study I was designed to explore the connection between basal NO synthesis and the myocardial function in the unstressed dog, and we have shown that aspecific NOS inhibition leads to an increased myocardial contractility in this setting. However, it also became evident that a single effect (i.e. a NO deficiency-induced contractile response) involved several dependent variables. The results revealed that the lack of NO is accompanied by significant ET-1 release. Furthermore, a myocardial XOR activity elevation is also involved in the consequences of nonspecific NOS inhibition, and this reaction likewise plays an important modulator role in this process. These experimental data therefore suggest a suppressive, regulatory role for endogenous NO: it restrains or counteracts these mechanisms, which would otherwise increase the cardiac contractility.

\section{Hemodynamic effects of NOS inhibition}

Our study has demonstrated the efficacy of NNA-induced NOS inhibition via a decreased plasma $\mathrm{NO}_{\mathrm{x}}$ level, together with prolonged increases in MAP and TPR and decreased CI and HR. NOS inhibitor treatment caused a decrease in the LV diastolic-systolic diameter difference, which points to an attenuation of the Frank-Starling response and might explain the decrease in CI (Prendergast 1997).

It has been evidenced that NO also influences HR by directly affecting the cardiac pacemaker activity, baroreflex transmission or the activity of the autonomic nervous system through enhancement of the bradycardic effects of vagal efferent (Balligand 1993, Conlon 1998). On the one hand, NO donors can inhibit the peripheral sympathetic neurotransmission by presynaptic reduction of the release of noradrenaline (Schwarz 1995, Choate 1999). On the other hand, the oral intake of an NOS inhibitor enhances baroreceptor reflex gain with decreased HR (Vasquez 1994). As a result of the multilevel HR regulation, diminished NO production potentiates the reflex bradycardia.

In our research protocol, the LV end-systolic pressure-diameter relationship was recorded as a preload-independent index of cardiac contractility (Goldfarb 1990). Consistent with our earlier results, NNA treatment caused a significant increase in heart contractility (Kaszaki 1996). Indeed, a detailed analysis of our experimental data suggested that the mechanism of the NNA-induced myocardial contractility elevation is a complex process which involves several variables (see explanation below). 


\section{NO effects on cardiac contractility}

Previous studies have demonstrated that high concentrations of endogenous NO can produce a negative inotropic effect (Brady 1993, Brunner 2001), primarily due to a reduction in myofilament responsiveness to $\mathrm{Ca}^{2+}$ (Brunner 2001). However, other groups have reported that the stimulation of myocardial NO production can offset the increase in contraction in response to a rise in intracellular $\mathrm{Ca}^{2+}$ (Kojda 1996, Casadei 2003).

Experiments with NO donors have often shown the opposing effects of NO on the myocardial contraction and HR. It has been revealed that the reaction is biphasic and dosedependent, i.e. low concentrations of NO donors (0.1-10 mM) increase the contractility and $\mathrm{HR}$, whereas higher concentrations (> $100 \mathrm{mM})$ elicit negative inotropic and chronotropic effects (Casadei 2003, Massion 2003, Gonzalez 2008).

Recent evidence has clearly demonstrated the critical role of NOS isoforms in the regulation of cardiac contractility: in nNOS-null mice, the inotropic response was suppressed, whereas in eNOS-deficient mice, the contractility was enhanced (Barouch 2002). Moreover, there is a spatial confinement of NO signaling in the heart. Specifically, in the sarcoplasmic reticulum, nNOS colocalizes with the ryanodine receptor, and the activation of nNOS positively modulates the cardiac contractility via the augmentation of $\mathrm{Ca}^{2+}$ release in response to frequency and $\beta$-adrenergic receptor stimulation. In contrast, the eNOS isoform is coupled to the $\beta_{3}$-adrenergic receptor and inhibits L-type $\mathrm{Ca}^{2+}$ channels, accordingly inhibiting $\beta$ adrenergic receptor-mediated increases in myocardial contractility (Barouch 2002, Casadei 2003).

Taken together, these findings indicate that, unlike eNOS, the cardiac nNOS isoform is an important physiological determinant of basal contractility in the mammalian myocardium, which suggests that nNOS-derived NO may exert a negative feedback control on $\mathrm{Ca}^{2+}$ entry, since an increase in intracellular $\mathrm{Ca}^{2+}$ would stimulate the nNOS synthesis of $\mathrm{NO}$, which in turn would inhibit $\mathrm{Ca}^{2+}$ influx through the L-type $\mathrm{Ca}^{2+}$ channels (Casadei 2003).

In light of these results, nonspecific NOS inhibition ignores the specialization and spatial confinement of signaling of the cardiac NOS isoforms, and effectively (in higher doses presumably more effectively) abrogates the modulator effect of the predominant NOS isoform.

An important consequence of NOS inhibition could be an imbalance in the positivenegative inotropy (vasoconstrictor-vasodilator) relationship, leading primarily to ET-1 release. Since NO may normally moderate ET-1 production and action (Boulanger 1990, Kourembanas 1993), the inhibition of NO synthesis can result in increased plasma levels of 
ET-1 (Richard 1995, Filep 1997). It has been demonstrated that, after acute NOS blockade, the predominant pressor mechanism is associated with a marked increase in ET-A/ET-B receptor activation rather than with increases in alpha-1, angiotensin 1 or vasopressin V1/V2 receptor activation (Banting 1996).

As far as we are aware, this is the first in vivo evidence of positive inotropy caused by ET-1 following NOS inhibition. Several aspects of the model highlight that the NNA-induced circulatory responses are characterized by predominantly ET-related immediate hemodynamic changes, demonstrating that this peptide is an important determinant of the increase in cardiac contractility. This observation supports the in vitro finding that NOS inhibition enhances the inotropic response to ET-1 (Kinnunen 2000). Exogenous ET-1 infusion may increase the in vivo cardiac contractility significantly, an effect that can be prevented by ET-A receptor antagonist pretreatment (Konrad 2005). In our study, the plasma ET-1 level gradually increased up to the end of the experiments, which may suggest that, after induction by NNA treatment, it was continuously replaced from the cellular sources. The results also revealed that the ET-1 peptide induced positive inotropy through the activation of ET-A receptors.

Recent evidence strongly suggests that the target area of NO and/or ET-1 is the same cellular microdomain for the modulation of cardiomyocyte contractility, via regulation of the L-type $\mathrm{Ca}^{2+}$ channels, but in the opposite sense (Casadei 2003, Robu 2003).

\section{Effects of ET-A receptor antagonism}

ET-A receptor antagonism by the ETR-P1/fl peptide proved effective in reducing the signs of vasoconstriction. As a result, the CI displayed an immediate significant increase and did not decline below the control level following NNA treatment, while the NOS inhibitioninduced elevation in TPR was lowered. Pretreatment with the ET-A receptor antagonist significantly elevated the plasma level of $\mathrm{NO}_{\mathrm{x}}$. This observation is in agreement with the data of Maeda et al., who demonstrated that an exercise-induced increase in ET-1 significantly lowered the plasma $\mathrm{NO}_{\mathrm{x}}$ concentration in the kidney, whereas pretreatment with an ET-A receptor antagonist resulted in significantly higher NO production (Maeda 2004). This elevation in NO production, presumably through activated ET-B receptor-induced NO release (Verhaar 1998), has a role in normalizing the LV diastolic-systolic diameter difference. Additionally, the plasma level of ET-1 was significantly lower and in this case the positive inotropic effect was missing. Hence, the volume per cardiac cycle increased, which maintained sufficient perfusion.

The ETR-p1/fl peptide, which was used in our study, has a special feature: it is an intramolecular complementary peptide of the ET-A receptors; as such, it can specifically 
recognize and bind the circulating ET-1 molecules (Baranyi 1995, Baranyi 1998). It has been shown that ETR-p1/fl peptide infusion in the same dose induces significant increases in CI and LV systolic-diastolic difference and significant decreases in TPR and plasma ET-1 level, while it does not influence the MAP, HR and cardiac contractility (Kaszaki 1997).

From the above results, it can be concluded that a deficit of ET-1 does not cause notable changes in macrohemodynamic parameters. Under normal, unstressed conditions, the regulatory effect of ET-1 could predominate at the level of the microcirculation. In contrast with the lack of ET-1, under conditions involving an NO shortage, both micro- and macrocirculatory disturbances and alterations in cardiac function can be observed, in which a significant role could be played by the elevated ET-1 level.

\section{Importance of interaction of myocardial nNOS and XOR}

In our study, NOS inhibition resulted in an increase in myocardial XOR activity. There is evidence that the activity of XOR, a major source of the production of reactive oxygen intermediates in the heart, is increased in the LV myocardium in nNOS-deficient mice (Khan 2004, Kinugawa 2005). Kinugawa et al. demonstrated spatially confined interactions between nNOS and XOR (Kinugawa 2005). These enzymes co-immunoprecipitate and colocalize in the sarcoplasmic reticulum of the cardiomyocytes, suggesting that nNOS gene deletion may have wider implications on the myocardial redox state. Additionally, NO has a direct inhibitory effect on XOR activity in vitro (Hassoun 1995). Hence, under normal circumstances, nNOS-derived NO inhibits XOR activity in a paracrine manner through the direct binding of NO to the iron-sulfur moiety of the enzyme (Hassoun 1995, Khan 2004). A deficiency of nNOS (but not eNOS) leads to a marked increase in XOR-mediated superoxide production and may contribute to a further reduction of the bioavailability of eNOS-derived $\mathrm{NO}$ in the myocardium, which in turn depresses myocardial excitation-contraction coupling (Khan 2004).

Indeed, many studies have shown that the superoxide radical produced by XOR decreases the myocardial contractility in a variety of cardiovascular pathologies. On the other hand, it has also been shown that the positive inotropic effect of ET-1 is mediated by mitochondrial reactive oxygen intermediates (Channon 2002, De Giusti 2008). Furthermore, ET-1 significantly increases intracellular superoxide levels in isolated normal cardiac myocytes (Caldiz 2007). It is important to note that XOR mimicked the effect of ET-1 in this system and, additionally, the effect of ET-1 was abolished by specific ET-A receptor antagonist treatment (Zeng 2008). Collectively, these in vitro observations, together with our in vivo data, suggest that ET-1 induces contractility changes via the stimulation of superoxide 
generation. Given the strong positive inotropic effects of ET-1, it will be important to determine how much of the NNA-induced contractility change is due to ET-1 and the extent to which it is influenced by superoxide radical production in normal cardiac tissue.

It should be noted that direct and indirect (or peripheral and central) effects of NOS and ET antagonism are difficult to distinguish in vivo. Taken together, the increase in LV contractility could be due to several factors, including increases in preload and coronary blood flow or the effects of reflex autonomic changes (e.g. baroreceptor responses). However, the results underline the significance of diminished NO production in myocardial XOR activity changes and ET-1 release, and these processes could contribute indirectly to the alterations in cardiac contractility through ET-A receptor activation.

In conclusion, secondary reactions linked to reduced NO production play important, and perhaps crucial roles in shaping NO-induced contractility changes in the normal myocardium. We propose that this pathway represents a homeostatic mechanism by which a mismatch between NO supply and demand in the cardiac muscle is translated into an increase in contractility.

\subsection{Discussion of Study II}

This study was designed to explore a connection between the increased peripheral flow-induced changes and cardiac contractility alterations. Another aim was to outline the role of NO in the HSD-evoked hemodynamic changes and to investigate the reliability of smallvolume resuscitation in conditions associated with diminished NO production.

The results revealed that generated vasoactive mediators are involved in HSD-induced circulatory changes and in alterations of cardiac contractility through NO-dependent and independent mechanisms, and suggest the preponderance of ET-1 in this process. Furthermore, it can be concluded, that HSD is less effective in NO-deficient states.

\section{Hemodynamic effects of HSD}

HSD solutions bring about rapid changes in the macro- and microhemodynamics in various circulatory beds. This could be related to a number of mechanisms, including the redistribution of fluid from the interstitium to the intravascular space; a direct relaxing action on the vascular smooth muscle; a blood fluidity improvement by hemodilution; and a stretchinduced ventricular dilatation caused by a pressure or volume overload (Janicki 2006). In our experiments, the molecular weight of the dextran component of the HSD solution was $40 \mathrm{kD}$. In vivo, solutions of $40 \mathrm{kD}$ dextran are advantageous when an improvement in blood flow is specifically required, while a higher molecular weight dextran (e.g. $70 \mathrm{kD})$ is preferable when 
a longer circulation time and a plasma volume expansion are the primary goals. The rationale of our approach was to achieve a rapid increase in flow velocity. Indeed, the HSD infusion resulted in prompt increases in MAP and $\mathrm{CO}$ and a decrease in TPR; the HR and coronary flow increased concomitantly, and a significant rise in myocardial contractility was noted in the early phase of the postinfusion period.

An expansion of the blood volume has been shown to increase the HR and blood pressure via the sympathetic nerves in a number of species, and this effect is based primarily on the activation of volume receptors at the venous-atrial junctions of the heart (Coote 2005). Stimulation of volume receptors by acute volume expansion results in an elevation of the plasma atrial natriuretic factor level, which correlates significantly with the right atrial pressure. An increase in atrial natriuretic factor level contributes to the elevation in preload, which could indirectly influence the LV contractility (Nakajima 2005). Blockade of the autonomic nervous system (by sinoaortic denervation, vagotomy or hexamethonium treatment) did not influence the increase in plasma atrial natriuretic factor level during volume expansion by $20 \mathrm{ml} / \mathrm{kg}$ dextran in lactated Ringer's solution (Kohara 1989, Otsuka 1989).

The increased LV preload might contribute to the positive inotropy, but the mechanism of the HSD-induced myocardial contractility elevation is rather complex, and this change can not be a simple consequence of an increased intravascular volume. This hemodynamic pattern could increase the coronary blood flow too (Gregg effect), which itself could lead to positive inotropy (Gregg 1963, Feigl 1983).

Several studies suggest the increased activity of the humoral positive inotropic agents in the case of volume expansion. Wade et al. and Elgjo et al. demonstrated elevations in plasma renin and norepinephrine following HSD or hypertonic saline infusion (Wade 1991, Elgjo 1994). Angiotensin II activation through AT1 receptors potentiates $\mathrm{Na}^{+} / \mathrm{H}^{+}$exchange activity, and an increase in intraneuronal $\mathrm{Na}^{+}$will lead to the excessive release of norepinephrine from the sympathetic neurons (Mackins 2006). Moreover, in human patients treated with the angiotensin convertase enzyme inhibitor quinapril, the plasma norepinephrine level did not change during a volume overload. This was not observed in the case of untreated patients (Volpe 1992).

It has been shown that an acute volume expansion caused by a rapid infusion of hypertonic colloid solution results in an increase in plasma ET-1 (Boldt 1994). Exogenous ET-1 infusion may increase the in vivo cardiac contractility significantly, an effect that can be prevented by ET-A receptor antagonist pretreatment (Konrad 2005). The results revealed that the plasma level of ET-1 increased significantly in this setup too, and the peptide induced 
positive inotropy through the activation of ET-A receptors (Eszlári 2008, Czóbel 2009). The plasma ET-1 level subsequently remained elevated until the end of the experiment, which may suggest that, after induction by HSD, it was continuously replaced from the endothelium or myocardial cells. Accordingly, it seems that HSD-induced mechanical stimuli result in an elevated protease output in the plasma (Mackins 2006), which can increase the formation of ET-1 from pre-pro ET or from big-ET (an elevated flux of proteases could be increase level of ET-1 preformed from its cellular sources).

The postinfusion period was characterized by significant rises in the plasma NO and ET-1 concentrations. NO and ET-1 release or synthesis are triggered by various mechanical stimuli, such as increased osmolarity due to by cell shrinkage (Schramek 1993), fluid shear stress on the endothelium (Kuchan 1993, Fissthaler 2000) and the physical stretching of smooth muscle vascular cells or cardiomyocytes (van Wamel 2001, Casadei 2003).

In our experiments, the volume expansion effected by the HSD infusion resulted in a moderate elevation of the plasma level of $\mathrm{NO}_{\mathrm{x}}$, an end-product of $\mathrm{NO}$, which could contribute positively to the LV contractility in this concentration. Although previous studies have indicated that excessive NO delivery from inflammatory cells (or cytokine-stimulated cardiomyocytes themselves) may result in profound cellular disturbances leading to attenuated cardiac contractility (Massion 2003), others have reported that the stimulation of myocardial NO production can offset the increase in contraction in response to a rise in intracellular $\mathrm{Ca}^{2+}$. Cardiac NO production is also activated by stretching and, under these conditions, NO has been shown to facilitate the Frank-Starling response and to contribute to the increase in intracellular $\mathrm{Ca}^{2+}$ transients that mediates the slow increase in contraction in response to stretching (Casadei 2003).

In the later phase of the postinfusion period, the HR gradually increased, the CI decreased and the myocardial contractility returned to a near-baseline level, while the TPR increased significantly. Further, these hemodynamic and biochemical changes were accompanied by enhanced myocardial MPO activity and decreases in myocardial cNOS activity. It has been proved in a number of diseases involving circulatory failure (myocardial infarction, cardiogenic shock, atherosclerosis and congestive heart failure) and also in surgical interventions that an increased ET-1 level is associated with decreased NO production (Warner 1999, Ovadia 2002). This marked decrease in NOS activity may be an indirect consequence of the elevation in ET-1 level. One possible explanation of this phenomenon is that the HSD-induced ET-1 release may be attributed to an increase in superoxide radical production, simultaneously with significant NO production, and this leads to the formation of 
peroxynitrite, a known inhibitor of NOS activity (Sheehy 1998, Ovadia 2002). Furthermore, ET-1 per se could inhibit endogenous NO synthesis through enhanced asymmetric dimethylarginine synthesis and ET-A receptor activation (Ohnishi 2002). On the other hand, peroxynitrite-mediated myocardial protein nitration has been associated with a depressed cardiac pump function. Borbely et al. proposed that alpha-actinin is a target for peroxynitrite in the human myocardium; and its nitration can induce a contractile dysfunction (Borbely 2005). Additionally, an in vivo interaction might occur between the increased nitrite level and myocardial MPO, affording reactive nitrosyl derivatives (Cooper 1992) and leading to protein nitration too.

\section{$\underline{\text { Effects of NNA pretreatment }}$}

Since the role of NO in regulating the cardiac function is complex and controversial, it was important to determine what proportions of the HSD-induced circulatory and myocardial contractility change were due to NO-dependent and to NO-independent mechanisms. Our findings with NNA pretreatment indicate that the HSD-induced hemodynamic changes were mediated mainly through NO-dependent mechanism.

NNA pretreatment definitely inhibited the HSD-evoked favorable hemodynamic features, the CI declined below the control level, and TPR increased enormously during the observation period. $\mathrm{HSD}$-induced $\mathrm{NO}_{\mathrm{x}}$ release was blocked by NNA pretreatment at 15 min of the postinfusion period. Moreover, the plasma level of ET-1 was significantly higher in the NNA+HSD group than in the HSD-only group. The extreme elevation of the ET-1 level could explain the increased TPR and venoconstriction, but ET-1-related positive chronotropy was not detected. As a result of NNA pretreatment, the HSD-induced HR elevation failed; it remained permanently at the control level. Our results are consistent with findings of the acute study by Pontieri et al., in which microinjections of a nonselective NOS inhibitor into the nucleus tractus solitarius increased the baroreceptor reflex gain with decreased HR in conscious normotensive rats (Pontieri 1998). In another study, the oral intake of an NOS inhibitor enhanced the baroreceptor reflex gain due to a potentiation of reflex bradycardia (Vasquez 1994). Inhibition of eNOS activity in the the nucleus tractus solitarius may increase the baroreceptor reflex gain via disinhibition (Waki 2003). Overall, it seems that HR regulation under volume expansion is an NO-dependent rather than an ET-1-dependent process.

NNA pretreatment did not influence the HSD-induced increase in LVD during the acute phase of volume expansion. Though NO largely accounts for the myocardial diastolic properties, the HSD-induced LVD increase seems to be NO-independent. This could be 
explained by the mechanical atrial stretch due to volume expansion, or by the high sodium concentration of the HSD infusion, which stimulates atrial natriuretic peptide release with an enhanced ventricular diastole (Arjamaa 1985). However, in the late phase of the postinfusion period, the effect of NNA pretreatment was characterized by a gradually decreased LVD with a lowered filling volume, because of the ET-1-induced venoconstriction.

Cardiac contractility is essentially dependent on oxygen supply and is characterized by an extremely high oxygen consumption. An HSD-induced volume expansion demands a higher energy supply, which is covered by an increased coronary flow. It has been evidenced that positive inotropy related to the increased utilization of ATP leading to the release of adenine nucleosides. Moreover, it has been demonstrated that exogenous ET-1 causes a significant elevation in the purine metabolism and stimulates adenosine release (Zima 2002). However, the inhibition of NO production reversed the cardiac contractility changes, with an extreme increase in plasma ET-1 level, which could be responsible for the decreased coronary perfusion (Juhász-Nagy 1999). Hence, the volume per cardiac cycle decreased to a level which was not able to maintain sufficient tissue perfusion. Accordingly, the diminished NO production with enhanced ET-1 release as an unfavorable side-effect of HSD fluid therapy could have a significant role in a cardiac power deficit. In the later phase of the postinfusion period, the coronary perfusion did not decrease under the control level, despite the decreased cardiac NO production. This could be explained by the enhanced level of adenosine originating from ATP breakdown, which is the main mediator of coronary metabolic adaptation in the heart (Kékesi 2002). It could be assumed that the gradual increase in cardiac contractility at the end of the observation period was due to the adapted cardiac perfusion with the energy supply. This late positive inotropy means that volume expansion can stimulate the release of other vasoconstrictors, and not only ET-1. In this regard, the roles of the renin-angiotensin system and catecholamines could be of interest (Mackins 2006). Overall, the HSD-induced positive inotropy proved an indirect NO-dependent process, which predominates through the coronary perfusion rather than through direct effects on cardiac contractility.

The data reported here demonstrate that HSD-induced mechanical stimuli cause significant peripheral NO and ET-1 release in the heart. This response may lead to an upset of the ET-1 - NO balance, an unfavorable side-effect of HSD fluid therapy. As a result of NNA pretreatment, the ET-1 - NO balance is disturbed mainly in the late phase of the postinfusion period, since the activity of NOS is decreased. The maintained NO production is absolutely necessary for normal peripheral and cardiac hemodynamic functions. Our results suggest that 
medication via HSD volume therapy could exert a negative influence on the outcome in numerous diseases associated with a decreased NO production (myocardial infarction, congestive heart failure, atherosclerosis and diabetes).

\section{SUMMARY OF NEW FINDINGS}

NO plays a vital role in controlling the peripheral circulation and myocardial contractility, and its lack could modify the circulatory regulation to a great extent. Our experimental data suggest a suppressive, regulatory role for endogenous NO: it restrains or counteracts several mechanisms, which would otherwise increase the cardiac contractility. The bioavailability of NO or its amount relative to other, vasoregulator, inotropic agents is of crucial importance.

I. A diminished NO production leads to secondary reactions by which a mismatch between NO supply and demand in the cardiac muscle is translated into an increase in cardiac contractility. A reduced NO synthesis leads to an increased superoxide production, a myocardial XOR activity elevation and preponderant vasoconstrictor effects, which decrease the $\mathrm{CO}$ and increase the myocardial contractility through an ET-A receptor-dependent mechanism.

II. HSD-induced mechanical stimuli cause significant peripheral NO and vasoconstrictor mediator release, and this response may lead to an upset of the NO - inotropic mediator balance. This is an unfavorable side-effect of HSD fluid therapy.

III. The positive inotropy is an indirect consequence of HSD administration. This NOdependent process predominates through coronary perfusion changes.

IV. Volume therapy with HSD creates a situation which is unfavorable from a hemodynamic aspect and could exert a negative influence on the outcome of circulatory conditions associated with a decreased NO production. 


\section{REFERENCES}

Arjamaa O, Vuolteenaho O: Sodium ion stimulates the release of atrial natriuretic polypeptides (ANP) from rat atria. Biochem Biophys Res Commun 132: 375-381, 1985.

Armistead CW Jr, Vincent JL, Preiser JC, De Backer D, Thuc Le Minh: Hypertonic saline solution-hetastarch for fluid resuscitation in experimental septic shock. Anesth Analg 69: 714720, 1989.

Balligand JL, Kelly RA, Marsden PA, Smith TW, Michel T: Control of cardiac muscle function by an endogenous nitric oxide signalling system. Proc Natl Acad Sci USA 90: 347$351,1993$.

Banting JD, Friberg P, Adams MA: Acute hypertension after nitric oxide synthase inhibition is mediated primarily by increased endothelin vasoconstriction. J Hypertens 14: 975-981, 1996.

Baranyi L, Campbell W, Ohshima K, Fujimoto S, Boros M, Okada H: The antisense homology box: a new motif within proteins that encodes biologically active peptides. Nat Med 1: 894-901, 1995.

Baranyi L, Campbell W, Oshima K, Fujimoto S, Boros M, Kaszaki J, Okada H.: Antisense homology box-derived peptides represent a new class of endothelin receptor inhibitors. Peptides 19: 211-223, 1998.

Barouch LA, Harrison RW, Skaf MW, Rosas GO, Cappola TP, Kobeissi ZA, Hobai IA, Lemmon CA, Burnett AL, O'Rourke B, Rodriguez ER, Huang PL, Lima JA, Berkowitz DE, Hare JM: Nitric oxide regulates the heart by spatial confinement of nitric oxide synthase isoforms. Nature 416 (6878): 337-339, 2002.

Beckman JS, Parks DA, Pearson JD, Marshall PA, Freeman BA: A sensitive fluorometric assay for measuring xanthine dehydrogenase and oxidase in tissues. Free Radical Biol Med 6: 607-615, 1989.

Bergentz S-E: Dextran in the prophylaxis of pulmonary embolism. World J Surg 2: 19-25, 1978.

Bode-Boger SM, Boger RH, Kienke S, Junker W, Frolich JC: Elevated Larginine/dimethylarginine ratio contributes to enhanced systemic NO production by dietary Larginine in hypercholesterolemic rabbits. Biochem Biophys Res Commun 219: 598-603, 1996. 
Boldt J, Knothe C, Zickmann B, Hammermann H, Stertmann WA, Hempelmann G: Volume loading with hypertonic saline solution: endocrinologic and circulatory responses. $J$ Cardiothorac Vasc Anesth 8: 317-323, 1994.

Borbely A, Toth A, Edes I, Virag L, Papp JG, Varro A, Paulus WJ, van der Velden J, Stienen GJ, Papp Z: Peroxynitrite-induced alpha-actinin nitration and contractile alterations in isolated human myocardial cells. Cardiovasc Res 67: 225-233, 2005.

Boulanger C, Luscher TF: Release of endothelin from the porcine aorta. Inhibition by endothelium-derived nitric oxide. J Clin Invest 85: 587-590, 1990.

Brady AJ, Warren JB, Poole-Wilson PA, Williams TJ, Harding SE: Nitric oxide attenuates cardiac myocyte contraction. Am J Physiol 265: H176-H182, 1993.

Brunner F, Andrew P, Wolkart G, Zechner R, Mayer B: Myocardial contractile function and heart rate in mice with myocyte-specific overexpression of endothelial nitric oxide synthase. Circulation 104:3097-3102, 2001.

Brutsaert DL: Cardiac endothelial-myocardial signaling: its role in cardiac growth, contractile performance, and rhythmicity. Physiol Rev 83: 59-115, 2003.

Buttery LD, Springall DR, Chester AH, Evans TJ, Standfield EN, Parums DV, Yacoub MH, Polak JM: Inducible nitric oxide synthase is present within human atherosclerotic lesions and promotes the formation and activity of peroxynitrite. Lab Invest 75: 77-85, 1996.

Caldiz CI, Garciarena CD, Dulce RA, Novaretto LP, Yeves AM, Ennis IL, Cingolani HE, Chiappe de Cingolani G, Pérez NG: Mitochondrial reactive oxygen species activate the slow force response to stretch in feline myocardium. J Physiol 584: 895-905, 2007.

Casadei B, Sears CE: Nitric-oxide-mediated regulation of cardiac contractility and stretch responses. Prog Biophys Mol Biol. 82: 67-80, 2003.

Channon M, Guzik TJ: Mechanisms of superoxide production in human blood vessels: relationship to endothelial dysfunction, clinical and genetic risk factors. J Physiol Pharmacol 53: 515-524, 2002.

Choate JK, Paterson DJ: Nitric oxide inhibits the chronotropic and inotropic responses to sympathetic nerve stimulation in the isolated guinea-pig atria. J Auton Nerv Syst 75: 100-108, 1999.

Conlon K, Collins T, Kidd C: The role of nitric oxide in the control by the vagal nerves of the heart of the ferret. Exp Physiol. 83: 469-480, 1998. 
Cooke JP, Tsao PS: Arginine: a new therapy for atherosclerosis? Circulation 95: 311-312, 1997.

Cooper CE, Odell E: Interaction of human myeloperoxidase with nitrite. FEBS Letters 314: 58-60, 1992.

Coote JH: A role for the paraventricular nucleus of the hypothalamus in the autonomic control of heart and kidney. Exp Physiol 90: 169-173, 2005.

Cotton JM, Kearney MT, MacCarthy PA, Grocott-Mason RM, McClean DR, Heymes C, Richardson PJ, Shah AM: Effects of nitric oxide synthase inhibition on basal function and the force-frequency relationship in the normal and failing human heart in vivo. Circulation 104: 2318-2323, 2001.

Czóbel M, Kaszaki J, Molnár G, Nagy S, Boros M: Nonspecific inhibition of nitric oxide synthesis evokes endothelin-dependent increases in myocardial contractility. Nitric Oxide Biol Chem 21: 201-209, 2009.

Davies PF: Endothelium as a signal transduction interface for flow forces: cell surface dynamics. Thrombosis and Haemostasis 70: 1-5, 1993.

De Giusti VC, Correa MV, Villa-Abrille MC, Beltrano C, Yeves AM, de Cingolani GE, Cingolani HE, Aiello EA: The positive inotropic effect of endothelin-1 is mediated by mitochondrial reactive oxygen species. Life Sci 83: 264-271, 2008.

Dixon LJ, Hughes SM, Rooney K, Madden A, Devine A, Leahey W, Henry W, Johnston GD, McVeigh GE: Increased superoxide production in hypertensive patients with diabetes mellitus: role of nitric oxide synthase. Am J Hypertens 18: 839-843, 2005.

Dries DJ: Hypotensive resuscitation. Shock 6: 311-316, 1996.

Elgjo GI, Eide I, Knardahl S: The role of the adrenal medulla in cardiovascular responses to hypertonic saline in haemorrhaged conscious rats. Acta Physiol Scand 151: 429-439, 1994.

Eszlári E, Czóbel M, Molnár G, Bogáts G, Kaszaki J, Nagy S, Boros M: Modulation of cardiac contractility through endothelin-1 release and myocardial mast cell degranulation. Acta Physiol Hun 95: 301-319, 2008.

Feigl EO: Coronary physiology. Physiol Rev 63: 1-205, 1983.

Filep JG: Endogenous endothelin modulates blood pressure, plasma volume, and albumin escape after systemic nitric oxide blockade. Hypertension 30: 22-28, 1997. 
Fissthaler B, Dimmeler S, Hermann C, Bussek R, Fleming I: Phosphorylation and activation of the endothelial nitric oxide synthase by fluid shear stress. Acta Physiol Scand 168: 81-88, 2000.

Flogel U, Merx MW, Godecke A, Decking UK, Schrader J: Myoglobin: a scavenger of bioactive NO. Proc Natl Acad Sci U S A 98: 735-740, 2001.

Frohlich ED: Prolonged local and systemic haemodynamic effects of hyperosmotic solutions. Arch Int Pharmacodyn 161: 154-166, 1966.

Godecke A, Heinicke T, Kamkin A, Kiseleva I, Strasser RH, Decking UK, Stumpe T, Isenberg G, Schrader J: Inotropic response to beta-adrenergic receptor stimulation and antiadrenergic effect of ACh in endothelial NO synthase-deficient mouse hearts. J Physiol 532: 195-204, 2001.

Goldfarb RD, Lee KJ, Andrejuk T, Dziuban SW Jr.: End-systolic elastance as an evaluation of myocardial function in shock. Circ Shock 30: 15-26, 1990.

Gonzalez DR, Fernandez IC, Ordenes PP, Treuer AV, Eller G, Boric MP: Differential role of S-nitrosylation and the NO-cGMP-PKG pathway in cardiac contractility. Nitric Oxide 18: 157-167, 2008.

Gonzalez-Castillo C, Rubio R, Zenteno-Savin T: Coronary flow-induced inotropism is modulated by binding of dextrans to the endothelial luminal surface. Am J Physiol Heart Circ Physiol 284:H1348-1357, 2003.

Gregg DE: Effect of coronary perfusion pressure or coronary flow on oxygen usage of the myocardium. Circ Res 13: 497-500, 1963.

Gyurko R, Kuhlencordt P, Fishman MC, Huang PL: Modulation of mouse cardiac function in vivo by eNOS and ANP. Am J Physiol Heart Circ Physiol 278: H971-H981, 2000.

Han X, Shimoni Y, Giles WR: An obligatory role for nitric oxide in autonomic control of mammalian heart rate. J Physiol 476: 309-314, 1994.

Hassoun PM, Yu FS, Zulueta JJ, White AC, Lanzillo JJ: Effect of nitric oxide and cell redox status on the regulation of endothelial cell xanthine dehydrogenase. Am J Physiol 268: L809L817, 1995.

Hibbs JB, Taintor RR, Vavrin Z, Rachlin EM: Nitric oxide: a cytotoxic activated macrophage effector molecule. Biochem Biophys Res Commun 157: 87-94, 1988. 
Ito N, Bartunek J, Spitzer KW, Lorell BH: Effects of the nitric oxide donor sodium nitroprusside on intracellular $\mathrm{pH}$ and contraction in hypertrophied myocytes. Circulation 95: 2303-2311, 1997.

Janicki JS, Brower GL, Gardner JD, Forman MF, Stewart JA Jr, Murray DB, Chancey AL: Cardiac mast cell regulation of matrix metalloproteinase-related ventricular remodeling in chronic pressure or volume overload. Cardiovasc Res 69: 657-665, 2006.

Juhász-Nagy A: Pathological action of endothelin-1 on the heart: coronary spasm and arrhythmia. Orv Hetil 140: 1395-1401, 1999.

Kaszaki J, Wolfard A, Bari F, Boros M, Parratt JR, Nagy S: Effect of nitric oxide synthase inhibition on myocardial contractility in anesthetized normal and endotoxemic dogs. Shock 6: 279-285, 1996.

Kaszaki J, Wolfárd A, Boros M, Baranyi L, Okada H, Nagy S: Effects of antiendothelin treatment on the early hemodynamic changes in hyperdynamic endotoxemia. Acta Chirurg Hung 36: 152-153, 1997.

Keaney JF, Hare JM, Balligand JL, Loscalzo J, Smith TW, Colucci WS: Inhibition of nitric oxide synthase augments myocardial contractile responses to beta-adrenergic stimulation. Am J Physiol 271: H2646-H2652, 1996.

Kékesi V, Zima E, Barát E, Juhász-Nagy A: Pericardial concentration of adenosine, inosine, and hypoxanthine in experimental model of spastic ischemia. Clin Sci (Lond) 103 (Suppl 48): S202-S205, 2002.

Kelly RA, Balligand JL, Smith TW: Nitric oxide and cardiac function. Circ Res 79: 363-380, 1996.

Khan SA, Lee K, Minhas KM, Gonzalez DR, Raju SV, Tejani AD, Li D, Berkowitz DE, Hare JM: Neuronal nitric oxide synthase negatively regulates xanthine oxidoreductase inhibition of cardiac excitation-contraction coupling. Proc Natl Acad Sci USA 101: 15944-15948, 2004.

Khan SA, Skaf MW, Harrison RW, Lee K, Minhas KM, Kumar A, Fradley M, Shoukas AA, Berkowitz DE, Hare JM: Nitric oxide regulation of myocardial contractility and calcium cycling: independent impact of neuronal and endothelial nitric oxide synthases. Circ Res 92: 1322-1329, 2003.

Kilbourn RG, Szabó C, Traber DL: Beneficial versus detrimental effects of nitric oxide synthase inhibitors in circulatory shock: lessons learned from experimental and clinical studies. Shock 7: 235-246, 1997. 
Kinnunen P, Szokodi I, Nicholls MG, Ruskoaho H: Impact of NO on ET-1- and AM-induced inotropic responses: potentiation by combined administration. Am J Physiol Regul Integr Comp Physiol 279: R569-R575, 2000.

Kinugawa S, Huang H, Wang Z, Kaminski PM, Wolin MS, Hintze TH: A defect of neuronal nitric oxide synthase increases xanthine oxidase-derived superoxide anion and attenuates the control of myocardial oxygen consumption by nitric oxide derived from endothelial nitric oxide synthase. Circ Res 96: 355-362, 2005.

Kohara K, Otsuka A, Mikami H, Katahira K, Tsunetoshi T, Ogihara T: Effects of the baroreceptor reflex system on atrial natriuretic factor secretion during volume expansion in dogs. Clin Sci (Lond) 77: 29-34, 1989.

Kojda G, Kottenberg K, Nix P, Schluter KD, Piper HM, Noack E: Low increase in cGMP induced by organic nitrates and nitrovasodilators improves contractile response of rat ventricular myocytes. Circ Res 78: 91-101, 1996.

Kojda G, Kottenberg K, Noack E: Inhibition of nitric oxide synthase and soluble guanylate cyclase induces cardiodepressive effects in normal rat hearts. Eur J Pharmacol 334: 181-190, 1997.

Konrad D, Oldner A, Wanecek M, Rudehill A, Weitzberg E, Biber B, Johansson G, Haggmark S, Haney M: Positive inotropic and negative lusitropic effects of endothelin receptor agonism in vivo. Am J Physiol Heart Circ Physiol 289: H1702-H1709, 2005.

Kourembanas S, McQuillan LP, Leung GK, Faller DV: Nitric oxide regulates the expression of vasoconstrictors and growth factors by vascular endothelium under both normoxia and hypoxia. J Clin Invest 92: 99-104, 1993.

Kramer GC, Perron PR, Lindsey DC: Small-volume resuscitation with hypertonic saline dextran solution. Surgery 100: 239-246, 1986.

Krausz MM: Controversies in shock research: hypertonic resuscitation - pros and cons. Shock 3: 69-72, 1995.

Kreimeier U, Frey L, Messmer K. Small-volume resuscitation. Anaesthesiology 6:400-408, 1993.

Kuchan MJ, Frangos JA: Shear stress regulates endothelin-1 release via protein kinase C and cGMP in cultured endothelial cells. Am J Physiol 264: H150-H156, 1993. 
Kuebler WM, Abels C, Schuerer L, Goetz AE: Measurement of neutrophil content in brain and lung tissue by a modified myeloperoxidase assay. Int J Microcirc Clin Exp 16: 89-97, 1996.

Mackins CJ, Kano S, Seyedi N, Schafer U, Reid AC, Machida T, Silver RB, Levi R: Cardiac mast cell-derived renin promotes local angiotensin formation, norepinephrine release, and arrhythmias in ischemia/reperfusion. J Clin Invest 116: 1063-1070, 2006.

Maeda S, Miyauchi T, Iemitsu M, Tanabe T, Goto K, Yamaguchi I, Matsuda M: Endothelin receptor antagonist reverses decreased NO system in the kidney in vivo during exercise. Am J Physiol Endocrinol Metab 286: E609-E614, 2004.

Massion PB, Feron O, Dessy C, Balligand JL: Nitric oxide and cardiac function: ten years after, and continuing. Circ Res 93: 388-398, 2003.

Mazzoni MC, Borgsrtöm P, Intaglietta M, Arfors K-E: Capillary narrowing in hemorrhagic shock is rectified by hyperosmotic saline-dextran reinfusion. Circulatory Shock 31:407-418, 1990.

Mohan P, Brutsaert DL, Paulus WJ, Sys SU: Myocardial contractile response to nitric oxide and cGMP. Circulation 93: 1223-1229, 1996.

Moncada S, Palmer RMJ, Higgs EA: Nitric oxide: physiology, pathophysiology and pharmacology. Pharmacol Rev 43: 109-142, 1991.

Moshage H, Kok B, Huizenga JR, Jansen PL: Nitrite and nitrate determinations in plasma: a critical evaluation. Clin Chem 41: 892-896, 1995.

Nakajima K, Onishi K, Dohi K, Tanabe M, Kurita T, Yamanaka T, Ito M, Isaka N, Nobori T, Nakano T: Effects of human atrial natriuretic peptide on cardiac function and hemodynamics in patients with high plasma BNP levels. Int J Cardiol 104: 332-337, 2005.

Ohnishi M, Wada A, Tsutamoto T, Fujii M, Matsumoto T, Yamamoto T, Takayama T, Wang X, Kinoshita M: Endothelin stimulates an endogenous nitric oxide synthase inhibitor, asymmetric dimethylarginine, in experimental heart failure. Clin Sci 103 S48: 241S-244S, 2002.

Otsuka A, Ogihara T, Mikami H, Kohara K, Katahira K, Tsunetoshi T, Kumahara Y: Contribution of the baroreflex afferent nerves to the production of vasoconstricted hypertension in volume-expanded dogs. Circ Res 65: 1467-1474, 1989. 
Ovadia B, Bekker JM, Fitzgerald RK, Kon A, Thelitz S, Johengen MJ, Hendricks-Munoz K, Gerrets R, Black SM, Fineman J: Nitric oxide-endothelin-1 interaction after acute ductal constriction in fetal lambs. Am J Physiol 282: H862-H871, 2002.

Palmer RM, Ashton DS, Moncada S: Vascular endothelial cells synthesize nitric oxide from L-arginine. Nature 333: 664-666, 1988.

Paulus WJ, Bronzwaer JG: Nitric oxide's role in the heart: control of beating or breathing? Am J Physiol Heart Circ Physiol 7: 8-13, 2004.

Paulus WJ, Vantrimpont PJ, Shah AM: Acute effects of nitric oxide on left ventricular relaxation and diastolic distensibility in humans. Assessment by bicoronary sodium nitroprusside infusion. Circulation 89: 2070-2078, 1994.

Pedersen EM, Agerbaek M, Kristensen IB, Yoganathan AP: Wall shear stress and early atherosclerotic lesions in the abdominal aorta in young adults. Eur J Vasc Endovasc Surg 13: 443-451, 1997.

Pontieri V, Venezuela MK, Scavone C, Michelini LC: Role of endogenous nitric oxide in the nucleus tractus solitarii on baroreflex control of heart rate in spontaneously hypertensive rats. J Hypertens 16: 1993-1999, 1998.

Prendergast BD, Sagach VF, Shah AM: Basal release of nitric oxide augments the FrankStarling response in the isolated heart. Circulation 96: 1320-1329, 1997.

Richard V, Hogie M, Clozel M, Loffler BM, Thuillez C: In vivo evidence of an endothelininduced vasopressor tone after inhibition of nitric oxide synthesis in rats. Circulation 91: 771$775,1995$.

Robu VG, Pfeiffer ES, Robia SL, Balijepalli RC, Pi Y, Kamp TJ, Walker JW: Localization of functional endothelin receptor signaling complexes in cardiac transverse tubules. J Biol Chem 278: 48154-48161, 2003.

Rourke MF, Mancia G: Arterial stiffness. J Hypertens 17: 1-4, 1999.

Rutherford RB, Jones DN: Does dextran improve graft patency? J Vascr Surg 1:765, 1988.

Schramek H, Gstraunthaler G, Willinger CC, Pfaller W: Hyperosmolality regulates endothelin release by Madin-Darby canine kidney cells. J Am Soc Nephrol 4: 206-213, 1993.

Schwarz P, Diem R, Dun NJ, Forstermann U: Endogenous and exogenous nitric oxide inhibits norepinephrine release from rat heart sympathetic nerves. Circ Res 77: 841-848, 1995. 
Sears CE, Bryant SM, Ashley EA, Lygate CA, Rakovic S, Wallis HL, Neubauer S, Terrar DA, Casadei B: Cardiac neuronal nitric oxide synthase isoform regulates myocardial contraction and calcium handling. Circ Res 92: e52-e59, 2003.

Seddon MD, Chowienczyk PJ, Brett SE, Casadei B, Shah AM: Neuronal nitric oxide synthase regulates basal microvascular tone in humans in vivo. Circulation 117: 1991-1996, 2008.

Shah AM, MacCarthy PA: Paracrine and autocrine effects of nitric oxide on myocardial function. Pharmacol Ther. 86: 49-86, 2000.

Shah AM, Spurgeon HA, Sollott SJ, Talo A, Lakatta EG: 8-Bromo-cGMP reduces the myofilament response to $\mathrm{Ca}^{2+}$ in intact cardiac myocytes. Circ Res 74: 970-978, 1994.

Sheehy AM, Burson MA, Black SM: Nitric oxide exposure inhibits endothelial NOS activity but not gene expression: a role for superoxide. Am J Physiol 274: L833-L841, 1998.

Shetty SS, Okada T, Webb RL, Del Grande D, Lappe R. W: Functionally distinct endothelin$\mathrm{B}$ receptors in vascular endothelium and smooth muscle. Biochem Biophys Res Commun 191: 459-467, 1993.

Steiner L, Kroncke K, Fehsel K, and Kolb-Bachofen V: Endothelial cells as cytotoxic effector cells: cytokine-activated rat islet endothelial cells lyse syngeneic islet cells via nitric oxide. Diabetologia 40: 150-155, 1997.

Sumner MJ, Cannon TR, Mundin JW, White DG, Watts IS: Endothelin ETA and ETB receptors mediate vascular smooth muscle contraction. Br. J Pharmacol. 107: 858-860, 1992. Suschek CV, Krischel V, Bruch-Gerharz D, Berendji D, Krutmann J, Kroncke KD, KolbBachofen V: Nitric oxide fully protects against UVA-induced apoptosis in tight correlation vessels. Arterioscler Thromb Vasc Biol 17: 2479-2488, 1997.

Szabó C, Mitchell JA, Thiemermann C, Vane JR: Nitric oxide-mediated hyporeactivity to noradrenaline precedes the induction of nitric oxide synthase in endotoxin shock. $\mathrm{Br} J$ Pharmacol 108: 786-792, 1993.

Tavernier B, Li JM, El Omar MM, Lanone S, Yang ZK, Trayer IP, Mebazaa A, Shah AM: Cardiac contractile impairment associated with increased phosphorylation of troponin I in endotoxemic rats. FASEB J 15: 294-296, 2001.

van Wamel AJ, Ruwhof C, van der Valk-Kokshoom LE, Schrier PI, van der Laarse A: The role of angiotensin II, endothelin-1 and transforming growth factor-beta as autocrine/paracrine mediators of stretch-induced cardiomyocyte hypertrophy. Mol Cell Biochem 218: 113-124, 2001. 
Vasquez EC, Cunha RS, Cabral AM: Baroreceptor reflex function in rats submitted to chronic inhibition of nitric oxide synthesis. Brazilian J Med Biol Res 27: 767-774, 1994.

Vassar MJ, Perry CA, Holcroft JW. Analysis of potential risks associated with $7.5 \%$ sodium chloride resuscitation of traumatic shock. Arch Surg 125: 1309-1315, 1990.

Velasco IT, Pontieri V, Rocha e Silva M, Lopes OU: Hyperosmotic $\mathrm{NaCl}$ and severe hemorrhagic shock. Am J Physiol 239: H664-H673, 1980.

Verhaar MC, Strachan FE, Newby DE, Cruden NL, Koomans HA, Rabelink TJ, Webb DJ: Endothelin-A receptor antagonist-mediated vasodilatation is attenuated by inhibition of nitric oxide synthesis and by endothelin-B receptor blockade. Circulation 97: 752-756, 1998.

Vollmar B, Menger MD: Volume replacement and microhemodynamic changes in polytrauma. Langenbecks Arch Surg 389: 485-491, 2004.

Volpe M, Tritto C, DeLuca N, Rubattu S, Mele AF, Lembo G, Enea I, deCampora P, Rendina V, Romano M: Angiotensin converting enzyme inhibition restores cardiac and hormonal responses to volume overload in patients with dilated cardiomyopathy and mild heart failure. Circulation 86: 1800-1809, 1992.

Wade C, Grady J, Kramer G. Efficacy of hypertonic saline dextran (HSD) in patients with traumatic hypotension: meta-analysis of individual patient data. Acta Anaesthesiol Scand Suppl 110: 77-79, 1997.

Wade CE, Hannon JP, Bossone CA, Hunt MM, Loveday JA, Coppes RI Jr, Gildengorin VL: Neuroendocrine responses to hypertonic saline/dextran resuscitation following hemorrhage. Circ Shock 35: 37-43, 1991.

Waki H, Kasparov S, Wong L-F, Murphy D, Shimizu T, Paton JFR: Chronic inhibition of endothelial nitric oxide synthase activity in nucleus tractus solitarii enhances baroreceptor reflex in conscious rats. $J$ Physiol 546: 233-242, 2003.

Warner TD: Relationships between the endothelin and nitric oxide pathways. Clin Exp Pharmacol Physiol 26: 247-252, 1999.

Yanagisawa M, Kurihara H, Kimura S, Tomobe Y, Kobayashi M, Mitsui Y, Yazaki Y, Goto K, Masaki T: A novel potent vasoconstrictor peptide produced by vascular endothelial cells. Nature 332: 411-415, 1988.

Younes RN, Aun F, Ching CT, Goldenberg DC, Franco MH, Miura FK, Santos SS, Sequeiros IM, Rocha e Silva, Fujimura I, Birolini D. Prognostic factors to predict outcome following the 
administration of hypertonic/hyperoncotic solution in hypovolemic patients. Shock 7: 79-83, 1997.

Zeng Q, Zhou Q, Yao F, O'Rourke ST, Sun C: Endothelin-1 regulates cardiac L-type calcium channels via $\mathrm{NAD}(\mathrm{P}) \mathrm{H}$ oxidase-derived superoxide. J Pharmacol Exp Ther 326: 732-738, 2008.

Zima E, Kékesi V, Nagy A, Juhász-Nagy AS: Endothelin-1 induced elevation in purine metabolite concentrations - autoregulatory protection in the canine pericardium? Clin Sci (Lond) 103 (Suppl 48): S198-S201, 2002.

Zimmermann T, Schuster R, Lauschke G, Trausch M: Chemiluminescence response of whole blood and separeted blood cells in cases of experimentally induced pancreatitis and MDTQDA-Trasylol-ascorbic acid therapy. Anal Chimica Acta 255: 373-381, 1991.

Drexler H, Zeiher K, Meinzer K, Just H: Correction of endothelial dysfunction in coronary microcirculation of hypercholesterolaemic patients by L-arginine. Lancet 338: 1546-1550, 1991.

\section{ACKNOWLEDGMENTS}

I owe may gratitude to Professor István Petri, head of the Department of Surgery at Bugyi István Hospital, for his inspiration and support of my experimental and scientific work.

I would like to express my gratitude to Professors Sándor Nagy and Mihály Boros, former and present heads of the Institute of Surgical Research, for their scientific guidance. I appreciate the constant support they gave me through the years during which I had the possibility to work in the institute.

I am especially grateful to my supervisor, József Kaszaki, for personal guidance and for introducing me to experimental surgery. Without his continuous encouragement, neverfailing interest, and optimistic attitude to the scientific problems, this $\mathrm{PhD}$ study might never have been completed.

Special thanks are due to all the technical staff of the Institute. Their skilful activities and enthusiastic work have helped me overcome many difficulties and have greatly facilitated the experiments.

Particular thanks are due to my wife, my parents and my whole family, who ensured an appropriate background for me to prepare this work. 


\section{ANNEX}

1. Czóbel M, Kaszaki J, Molnár G, Nagy S, Boros M: Nonspecific inhibition of nitric oxide synthesis evokes endothelin-dependent increases in myocardial contractility. Nitric Oxide Biol Chem 21: 201-209, 2009.

2. Molnár G, Eszlári E, Czóbel M, Kaszaki J, Bogáts G, Nagy S, Boros M: A nitrogénmonoxid-szintézis gátlása endothelinfüggő szívkontraktilitás növekedéshez vezet. Cardiologica Hungarica 40(1): 1-6, 2010.

3. Eszlári E, Czóbel M, Molnár G, Bogáts G, Kaszaki J, Nagy S, Boros M: Modulation of cardiac contractility through endothelin-1 release and myocardial mast cell degranulation. Acta Physiol Hun 95:301-319, 2008.

4. Molnár G, Kaszaki J, Eszlári E, Géczi T, Nagy S, Petri I, Boros M: Interaction of endothelin and nitric oxide in cardiac effects of colloid-crystalloid volume expansion. Perfusion 8: 366, 2000. 